\title{
Activation of Intrinsic Afferent Pathways in Submucosal Ganglia of the Guinea Pig Small Intestine
}

\author{
Hui Pan and Michael D. Gershon \\ Department of Anatomy and Cell Biology, Columbia University College of Physicians and Surgeons, New York, \\ New York 10032
}

The enteric nervous system contains intrinsic primary afferent neurons that allow mucosal stimulation to initiate reflexes without CNS input. We tested the hypothesis that submucosal primary afferent neurons are activated by 5-hydroxytryptamine (5-HT) released from the stimulated mucosa. Fast and/or slow EPSPs were recorded in submucosal neurons after the delivery of exogenous 5-HT, WAY100325 (a 5- $\mathrm{HT}_{1 \mathrm{P}}$ agonist), mechanical, or electrical stimuli to the mucosa of myenteric plexus-free preparations ( \pm extrinsic denervation). These events were responses of second-order cells to transmitters released by excited primary afferent neurons. After all stimuli, fast and slow EPSPs were abolished by a $5-\mathrm{HT}_{1 \mathrm{P}}$ antagonist, $\mathrm{N}$-acetyl-5hydroxytryptophyl-5-hydroxytryptophan amide, and by $1.0 \mu \mathrm{M}$ tropisetron, but not by 5- $\mathrm{HT}_{4}$-selective antagonists (SB204070 and GR113808A) or 5- $\mathrm{HT}_{3}$-selective antagonists (ondansetron and $0.3 \mu \mathrm{M}$ tropisetron). Fast EPSPs in second-order neurons were blocked by hexamethonium, and most slow EPSPs were blocked by an antagonist of human calcitonin gene-related peptide $\left(\mathrm{hCGRP}_{8-37}\right)$. hCGRP $_{8-37}$ also inhibited the spread of excitation in the submucosal plexus, assessed by measuring the uptake of FM2-10 and induction of c-fos. In summary, data are consistent with the hypothesis that 5-HT from enterochromaffin cells in response to mucosal stimuli initiates reflexes by stimulating $5-\mathrm{HT}_{1 \mathrm{P}}$ receptors on submucosal primary afferent neurons. Second-order neurons respond to these cholinergic/ CGRP-containing cells with nicotinic fast EPSPs and/or CGRPmediated slow EPSPs. Slow EPSPs are necessary for excitation to spread within the submucosal plexus. Because some second-order neurons contain also CGRP, primary afferent neurons may be multifunctional and also serve as interneurons.

Key words: serotonin; 5-hydroxytryptamine; 5-HT receptors; 5-HT1P receptor; 5-HT3 receptor; enteric nervous system; ENS; autonomic nervous system; gut; intestine; sensory neurons
The gut is the only organ capable of manifesting reflex activity in the absence of input from the CNS (Furness and Costa, 1987; Gershon et al., 1994; Furness et al., 1995a). These secretory (Cooke, 1989) or peristaltic reflexes can occur because the enteric nervous system (ENS) contains primary afferent neurons. Mucosal stimulation is thought to activate intrinsic primary afferent neurons in both submucosal (Bülbring et al., 1958; Kirchgessner et al., 1992, 1996; Cooke et al., 1997) and myenteric plexuses (Kunze et al., 1995; Bertrand et al., 1997; Furness et al., 1998). Distension of other layers of the gut also elicits reflexes mediated by stretch-sensitive myenteric neurons (Kunze et al., 1998) or collaterals of extrinsic sensory neurons (Grider and Jin, 1994).

Peristaltic reflexes require a viable mucosa (Bülbring et al., 1958) and intact submucosal-myenteric plexus connections (Tsuji et al., 1992). Secretory reflexes depend only on submucosal neurons because they can be evoked in preparations that lack myenteric ganglia (Cooke et al., 1997). Mucosal enterochromaffin (EC) cells have been proposed to be sensory transducers that respond to luminal stimuli by secreting 5 -HT into the intestinal wall to stimulate primary afferent neurons (Bülbring and Crema, 1958, 1959a,b; Bülbring and Lin, 1958; Bülbring et al., 1958). 5-HT secreted by EC cells stimulates enteric neurons (Wade et al., 1990; Kirchgessner et al., 1992, 1996) and initiates peristaltic

\footnotetext{
Received Dec. 8, 1999; revised Feb. 9, 2000; accepted Feb. 11, 2000.

This work was supported by National Institutes of Health Grant NS12969.

Correspondence should be addressed to Dr. Hui Pan, Department of Anatomy and Cell Biology, Columbia University College of Physicians and Surgeons (P\&S 12-513), 630 West 168th Street, New York, NY 10032. E-mail: hp42@columbia.edu. Copyright (C) 2000 Society for Neuroscience $0270-6474 / 00 / 203295-15 \$ 15.00 / 0$
}

(Foxx-Orenstein et al., 1995; Grider et al., 1996; Wade et al., 1996) and secretory reflexes (Sidhu and Cooke, 1995; Cooke et al., 1997). The 5-HT transporter (SERT) is expressed by mucosal epithelial cells and inactivates 5-HT released in the mucosa (Wade et al., 1996; Chen et al., 1998). The hypothesis that 5-HT initiates the peristaltic reflex has been questioned because the reflex persists in rats on a tryptophan-deficient diet to reduce levels of 5-HT (Boullin, 1964). Tryptophan-deficient diets, however, do not reduce the enteric 5-HT level to zero and may have altered reflex threshold or sensitivity, which was not investigated.

Mucosal stimuli that have been reported to excite enteric primary afferent neurons include 5-HT (Kirchgessner et al., 1992, 1996; Bertrand et al., 1997; Cooke et al., 1997; Furness et al., 1998), $\mathrm{N}_{2}$ puffs (Kirchgessner et al., 1992, 1996), mechanical stroking (Foxx-Orenstein et al., 1995; Cooke et al., 1997), acid (Bertrand et al., 1997; Furness et al., 1998), cholera toxin (Cassuto et al., 1982, 1983; Nilsson et al., 1983; Beubler et al., 1989; Jiang et al., 1993), and electrical shocks (Bertrand et al., 1997; Furness et al., 1998). Methods used in previous studies to identify responding submucosal neurons have included measurements of neuronal cytochrome oxidase activity (Mawe and Gershon, 1986; Kirchgessner et al., 1990), induction of the $c$-fos proto-oncogene (Kirchgessner et al., 1992), and uptake of the activity probes FM1-43 and FM2-10 (Kirchgessner et al., 1996). The primary afferent pathways of the submucosal plexus have not been previously evaluated electrophysiologically, although such studies have been directed at their myenteric counterparts (Bertrand et al., 1997; Furness et al., 1998).

The current study was undertaken to confirm that submucosal 


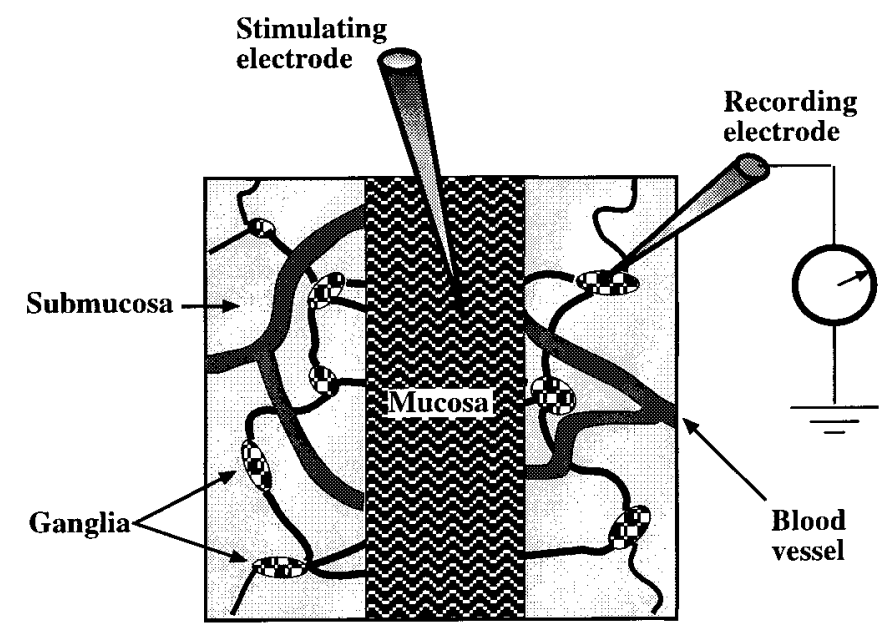

Figure 1. Diagram showing the mucosa-submucosa preparation used to study the effects of mucosal stimulation on the activity of submucosal neurons. The myenteric plexus is removed to permit submucosal responses to be analyzed in the absence of confounding effects from myenteric neurons. A central segment of mucosa was left intact (facing up) for stimulation but was elsewhere stripped away to permit the submucosal plexus to be visualized. The submucosal ganglia that were selected for recording were those that were adjacent to the mucosal edge and positioned on a connective that appeared to run toward the site of stimulation.

intrinsic primary afferent neurons are activated by 5-HT released from the intestinal mucosa in response to mechanical stimulation, to determine which 5-HT receptor subtype(s) mediates this effect, and to identify the neurotransmitter(s) used by the neurons activated by 5-HT. Stimuli were applied in vitro to an intact patch of mucosa while intracellular records were simultaneously obtained from impaled submucosal neurons. Electrophysiological observations were supported by measurements of the uptake of FM2-10, induction of $c$-fos, and the immunocytochemical identification of responding neurons. The data suggest that endogenous 5-HT released from the stimulated mucosa activates submucosal intrinsic primary afferent neurons by stimulating $5-\mathrm{HT}_{1 \mathrm{P}}$ receptors and that these neurons evoke fast and slow EPSPs in secondorder cells. All of these fast EPSPs are cholinergic (nicotinic), but cholinergic (muscarinic) slow EPSPs are rare. Most of the slow EPSPs are mediated by calcitonin gene-related peptide (CGRP).

\section{MATERIALS AND METHODS}

Tissue preparation. Male guinea pigs weighing 250-350 gm were euthanized by $\mathrm{CO}_{2}$ inhalation as approved by the Animal Care and Use Committee of Columbia University. A segment of ileum was excised $10-20 \mathrm{~cm}$ proximal to the ileocecal junction and placed in oxygenated $\left(95 \% \mathrm{O}_{2} / 5 \% \mathrm{CO}_{2}\right.$ ) Krebs solution of the following composition (in $\mathrm{mM}$ ): $\mathrm{NaCl} 121.3, \mathrm{KCl}$ 5.95, $\mathrm{CaCl}_{2} 2.5, \mathrm{NaHCO}_{3} 14.3, \mathrm{NaH}_{2} \mathrm{PO}_{4} 1.34, \mathrm{MgCl}_{2}$ 1.2 , and glucose 11.5 . A $1.5 \mathrm{~cm}$ segment of ileum was cut open along the mesenteric border and pinned out flat (mucosal surface up) in a Petri dish lined with a silicone elastomer. The mucosa and submucosa were dissected from the muscularis externa under microscopic control. The muscular layers, containing the myenteric plexus, were discarded, and the isolated mucosa-submucosa preparation was pinned to a second elastomer-lined dish with the mucosal side facing up. The mucosa was then dissected away on two sides, such that only a $\sim 1.5 \mathrm{~mm}$ column of mucosa was left intact in the center of the preparation (Fig. 1). Removal of the mucosa exposed the submucosa, permitting submucosal ganglia to be visualized in the exposed region and impaled with microelectrodes. The final 5-8 $\times 5-8 \mathrm{~mm}$ preparation was transferred to a small recording chamber (volume $=0.5-0.7 \mathrm{ml}$ ) and secured by pinning to an elastomercoated surface. The tissue was superfused at $36^{\circ} \mathrm{C}$ with oxygenated Krebs solution flowing at a rate of $3.5 \mathrm{ml} / \mathrm{min}$.

Extrinsic denervation. In three animals, extrinsic nerves to a loop of intestine were cut and allowed to degenerate (Galligan et al., 1988; Li et al., 1998). Each guinea pig was anesthetized by an intraperitoneal injection of a mixture of ketamine $(90 \mathrm{mg} / \mathrm{kg})$ and xylazine $(13.5 \mathrm{mg} / \mathrm{kg})$. A loop of ileum was identified that was clearly supplied by a single mesenteric artery. A fine forceps was used to strip the nerve fiber bundles from the artery and accompanying vein under microscopic control. The vessels were then painted with $80 \%$ phenol in distilled water, and nerves were again cut away. The denervated region was marked by placing a loose ligature around the vascular supply of the loop of gut. The bowel was then returned to the abdomen, the wound was closed, and the guinea pig was permitted to recover. Animals were killed $7 \mathrm{~d}$ after the operation, and the denervated (experimental) loop of bowel along with a nondenervated (control) loop was removed and processed as described above for recording from submucosal neurons. To verify the extent of extrinsic denervation, the sympathetic innervation was demonstrated immunocytochemically with antibodies to tyrosine hydroxylase (TH; see below). The sympathetic nerves were used as a surrogate extrinsic neural marker, because the sensory transmitters, CGRP and substance P, are contained in both intrinsic and extrinsic fibers (Gershon et al., 1994).

Mucosal stimulation. To restrict the size of the stimulated region, a micropipette (tip size 20-30 $\mu \mathrm{m}$ ) filled with Krebs solution \pm 5-HT (1 $\mathrm{mm}$ ) or other agonists was used in all experiments to stimulate the mucosa. For those studies in which the mucosa was to be stimulated with puffs of $\mathrm{N}_{2}$, the micropipette was left unfilled. The agonist-containing solutions or puffs of $\mathrm{N}_{2}$ gas were ejected from the micropipette by pressure $(9-12$ psi, pulse duration $=0.2-1 \mathrm{sec})$ delivered by a multichannel picospritzer (General Valve, Fairfield, NJ). The small stimulus site in the mucosa was located downstream from the level of the recording electrode, so that agonists delivered to the mucosa would be carried away by the superfusing solution and would not flow back to the recording site. The distance between the recording and stimulating electrodes was $\sim 2$ $\mathrm{mm}$. Mechanical stimuli were also applied to the mucosa with a blunt glass micropipette or a similar pipette tipped with a sponge. These pipettes were prepared by pulling a glass micropipette as for recording and then breaking off the tip and fire-sealing the broken end. The resulting smooth glass ball at the pipette tip had a diameter of $\sim 1 \mathrm{~mm}$. When a sponge was attached, the spongy material was ligated to the pipette tip, enlarging the effective tip diameter to $1.5-2 \mathrm{~mm}$. The pipette was lowered under visual control until just short of the tip of a villus, after which a piezoelectric motor (Stoelting, Wood Dale, IL)-driven micromanipulator was used to lower the pipette by $200 \mu \mathrm{m}$ in $10 \mu \mathrm{m}$ steps. The pipette was allowed to apply pressure to the mucosal surface for $10-20 \mathrm{sec}$ and then was raised. To activate mucosal nerve fibers directly, electrical stimuli (single rectangular pulses, $0.5 \mathrm{msec}$ duration, 15-30 mA) were delivered via a silver cable to the stimulating microelectrode, now filled with agonist-free Krebs solution. Stimuli, particularly mechanical stimuli, were delivered with great care to prevent dislodging the recording micropipette.

Intracellular recording. Submucosal ganglia were visualized using Hoffman modulation-contrast optics at $10 \times$ magnification. The ganglia selected for recordings were always ones from which an interganglionic fiber tract running toward the mucosa could be recognized. There were never any intervening ganglia between the recording site and the point at which the interganglionic connective disappeared under the intact mucosa. Intracellular recordings were obtained from neurons using glass microelectrodes (tip resistances $90-160 \mathrm{M} \Omega$ ) filled with $2.0 \mathrm{M} \mathrm{KCl}$ or 1.0 $\mathrm{M} \mathrm{KCl}$ containing $2 \%$ Neurobiotin (Vector Laboratories, Burlingame, CA). An amplifier with an active bridge circuit (Axoclamp 2B, Axon Instruments, Foster City, CA) was used to record the transmembrane potential difference and synaptic potentials, as well as to inject Neurobiotin into the neuron by iontophoresis via the recording electrode.

Immunocytochemistry. After electrophysiological recordings, preparations were fixed for $3 \mathrm{hr}$ with $4 \%$ formaldehyde (freshly prepared from paraformaldehyde) in $0.1 \mathrm{M}$ sodium phosphate buffer, $\mathrm{pH} 7.4$, at room temperature and washed with PBS $(3 \times 10 \mathrm{~min})$. To locate neurons that had been injected with Neurobiotin in the tissue from which recordings were obtained, the preparations were incubated with streptavidin coupled to fluorescein isothiocyanate (FITC) (diluted 1:200; Kirkegaard and Perry, Gaithersburg, MD) or cyanine 3 (Cy3) (diluted 1:2000; Jackson Immunoresearch Laboratories, West Grove, PA) for $2 \mathrm{hr}$ at room temperature. Free-floating whole-mount preparations were exposed to PBS containing $1.0 \%$ Triton $\mathrm{X}-100$ and $4 \%$ horse serum for $30 \mathrm{~min}$ to permeabilize the tissue and reduce background staining. Immunoreactivity was then demonstrated by incubating the preparations with primary antibodies in a humidified chamber overnight at room temperature. 
Table 1. Primary immune reagents

\begin{tabular}{|c|c|c|c|c|}
\hline Antibody specificity & Antibody type & Dilution & Source & Reference \\
\hline Neuropeptide Y (NPY) & Rabbit polyclonal & $1: 1000$ & $\begin{array}{l}\text { Peninsula Laboratories, Bel- } \\
\text { mont, CA }\end{array}$ & Branchek and Gershon (1989) \\
\hline Calcitonin gene-related peptide (CGRP) & Rabbit polyclonal & $1: 1000$ & Peninsula & Branchek and Gershon (1989) \\
\hline Calretinin & Rabbit polyclonal & $1: 800$ & $\begin{array}{l}\text { Chemicon International, } \\
\text { Temecula, CA }\end{array}$ & Brookes et al. (1991) \\
\hline Calbindin & Mouse monoclonal & $1: 200$ & Sigma & $\begin{array}{l}\text { Pompolo and Furness (1988); } \\
\text { Furness et al. (1990); } \\
\text { Pan et al. (1997) }\end{array}$ \\
\hline Tyrosine hydroxylase & Rabbit polyclonal & $1: 500$ & EugeneTech, Ridgefield, NJ & Li et al. (1998) \\
\hline $\begin{array}{l}\text { c-Fos }\{\text { sc- } 52-\mathrm{G}\} \text { epitope }=\text { amino acids } \\
(210-235 \text { of human c-FOS, no cross- } \\
\text { reaction with Fos B, Fra-1, or Fra- } 2)\end{array}$ & Rabbit polyclonal & $3 \mu \mathrm{l} / \mathrm{ml}$ & $\begin{array}{l}\text { Santa Cruz Biotechnology, } \\
\text { Santa Cruz, CA }\end{array}$ & Kirchgessner et al. (1992) ${ }^{a}$ \\
\hline
\end{tabular}

${ }^{a}$ The results obtained with this antibody were identical to those obtained in the referenced study.

The primary antibodies that were used are listed in Table 1. Bound primary antibodies were visualized by incubating tissues for $2 \mathrm{hr}$ at room temperature with affinity-purified goat anti-rabbit or anti-mouse secondary antibodies labeled with tetramethylrhodamine isothiocyanate (TRITC) (diluted 1:200; Kirkegaard and Perry) or FITC (diluted 1:200) or Cy3 (diluted 1:2000). Immunostained tissues were examined with a Leica DMRB microscope equipped for vertical fluorescence microscopy. FITC fluorescence was detected using a Leica L2 filter cube (exciting filter band pass $470-490 \mathrm{~nm}$; dichroic mirror reflection short pass 510 $\mathrm{nm}$; suppression filter band width $520 \mathrm{~nm}$ ). TRITC or Cy3 fluorescence were detected using a Leica M2 filter cube (exciting filter band pass $546 / 14 \mathrm{~nm}$; dichroic mirror reflection short pass $580 \mathrm{~nm}$; edge wavelength $580 \mathrm{~nm})$. There was not cross-detection between the FITC- and the TRITC- or Cy3-selective dichroic mirror-filter cubes.

1,1'-Dioctadecyl-3,3,3',3'-tetramethylindocarbocyanine perchlorate (DiI) (large crystals; Molecular Probes, Eugene, OR) was used to trace nerve fiber connections between the stimulus and recording sites. After electrophysiological records were obtained, DiI-coated glass beads (three to five, $200 \mu \mathrm{M}$ diameter, Sigma, St. Louis, MO) were placed on the mucosal site where stimuli had been applied. Three to five beads were used to label as many nearby nerve fibers as possible. The tissue was then incubated at $37^{\circ} \mathrm{C}$ with $2 \%$ formaldehyde in PBS for $\sim 1$ week to allow the DiI to label fully all neurons projecting to the vicinity of the site of stimulation.

Visualization of neurons activated by mucosal stimuli. Two methods were used to investigate the population of neurons that had become active in response to stimuli (mechanical stimulation or 5-HT) applied to the mucosa. One was to study the uptake of the styryl dye, FM2-10 [N-(3-(triethylammoniumpropyl)-4-(4-dibutylamino)styryl) pyridinium dibromide (Molecular Probes)]. FM2-10 is a water-soluble dye that inserts into the outer leaflet of the plasma membranes of neurons and is taken up when synaptic vesicles recycle (Betz and Bewick, 1992; Betz et al., 1992). FM2-10 is nonfluorescent in aqueous medium but becomes intensely fluorescent in membranes. Fluorescent vesicles eventually label neuronal perikarya by retrograde transport from their sites of uptake. Because enteric neurites are quite short and vesicles may also recycle from perikaryal membranes, the cell bodies of active neurons become labeled within minutes of the addition of FM2-10 (Kirchgessner et al., 1996). Because the number of vesicles that recycle increases in proportion to neuronal activity, physiological stimulation increases the number of FM2-10-labeled internal vesicles. The nonactivity-dependent fluorescence of cell surfaces washes off within $15 \mathrm{~min}$, but the internal vesicular fluorescence, which is activity dependent, persists.

To study the effects of mechanical stimulation on uptake of FM2-10, the mucosa and submucosa were dissected from the guinea pig small intestine. The mucosa of the resulting preparations ( $2 \mathrm{~cm}$ in length) was not cut away as for electrophysiological recording but was left undisturbed before stimulation. The intact mucosa in the caudal half of the preparation was stroked for $5 \mathrm{~min}$ (in the oral to anal direction) with a soft sponge brush, whereas the rostral half was left alone and served as a nonstimulated control. The tissue was superfused with Krebs solution containing FM2-10 $\left(50 \mu \mathrm{M} ; 3.5 \mathrm{ml} / \mathrm{min} ; 36^{\circ} \mathrm{C}\right)$ during stroking. After stimulation, superfusion was continued at $4^{\circ} \mathrm{C}$ with FM2-10-free Krebs solution to allow the nonactivity-dependent fluorescence to wash out of the tissue. After mucosa was removed, surviving preparations were examined by vertical fluorescence microscopy (using the N-2.1 filter cube) to detect the fluorescence of FM2-10 in the submucosal plexus. Neurons labeled with FM2-10 were counted in both the stimulated and control regions of each preparation. In some experiments, the internal activity-dependent FM2-10 was photoconverted in the presence of 3, 3 '-diaminobenzidine (DAB) to identify the FM2-10-labeled cells after fixation of the tissue. Because DAB persists in fixed tissue, it was possible to subject the preparations to immunocytochemistry to investigate the neuropeptide content of neurons that took up FM2-10. For photoconversion, preparations that had been exposed to FM2-10 were observed microscopically, and fluorescent neurons were identified. DAB (1.5 $\mathrm{mg} / \mathrm{ml}$ in Tris buffer $0.1 \mathrm{M}, \mathrm{pH} 8.2$ ) was then added to the incubating solution, and the cells were exposed to exciting light (passed through the Leica N-2.1 filter cube) until the red fluorescence of FM2-10 was replaced with a brown color in the labeled neurons. Tissues were then fixed with $4 \%$ formaldehyde and prepared for immunocytochemistry as described above.

The second method that was used to detect activated neurons was to visualize their Fos immunoreactivity (Morgan and Curran, 1991; Kirchgessner et al., 1992). Similar preparations were obtained; however, the mucosa was stimulated for 45 min with puffs of $\mathrm{N}_{2}$ delivered from the tip of a micropipette (Kirchgessner et al., 1992) as described above. In this case, a separate nonstimulated preparation from the same animal served as a control. Both the stimulated and control preparations were fixed with cold acetone for $10 \mathrm{~min}$ and incubated with antibodies to Fos (Table 1). Several batches of antibodies to Fos were investigated. As reported previously, many other antibodies immunostained the nuclei of neurons even in the absence of stimulation (Parr and Sharkey, 1994). It is necessary to use antibodies that do not cross-react with Fos-related antigens or other constitutive oncoproteins to demonstrate activitydependent Fos immunoreactivity. Bound primary antibodies were visualized by incubating tissues for $2 \mathrm{hr}$ at room temperature with biotinylated goat anti-rabbit secondary antibodies (diluted 1:400; Kirkegaard and Perry) and avidin-Cy3 (diluted 1:2000; Kirkegaard and Perry).

Drugs and chemicals. Agonists used for mucosal stimulation included 5-HT creatinine sulfate (Sigma), Way 100325 (Wyeth Ayerst Pharmaceutical), and BIMU-8 (Boehringer-Ingelheim). The interval between applications of each agonist was at least 5 min to prevent desensitization of 5-HT receptors. Antagonists were studied by adding them to the superfusing solution at least $15 \mathrm{~min}$ before stimulation of the mucosa with an agonist or $\mathrm{N}_{2}$. The antagonists that were investigated included tetrodotoxin (TTX; Sigma), hexamethonium (C6; Sigma), $\omega$-conotoxin (RBI, Natick, MA), fluoxetine (RBI), $N$-acetyl-5-hydroxytryptophy-5hydroxytryptophan (5-HTP-DP; New York State Psychiatric Institute), ondansetron (GlaxoWellcome Research and Development, Greenford, UK), tropisetron (Sandoz Pharmaceutical, Basel, Switzerland), GR113808A (GlaxoWellcome), SB-204070 (SmithKline Beecham, Betchworth, UK), GR94800 (RBI), Men 10376 (RBI), [ \pm ]-3-(2-carboxypiperazin-4-yl)-propyl-1-phosphonic acid (CPP; RBI), Win 51708 (RBI), NK 4-10 (RBI), and scopolamine (RBI). Peptides that were examined 

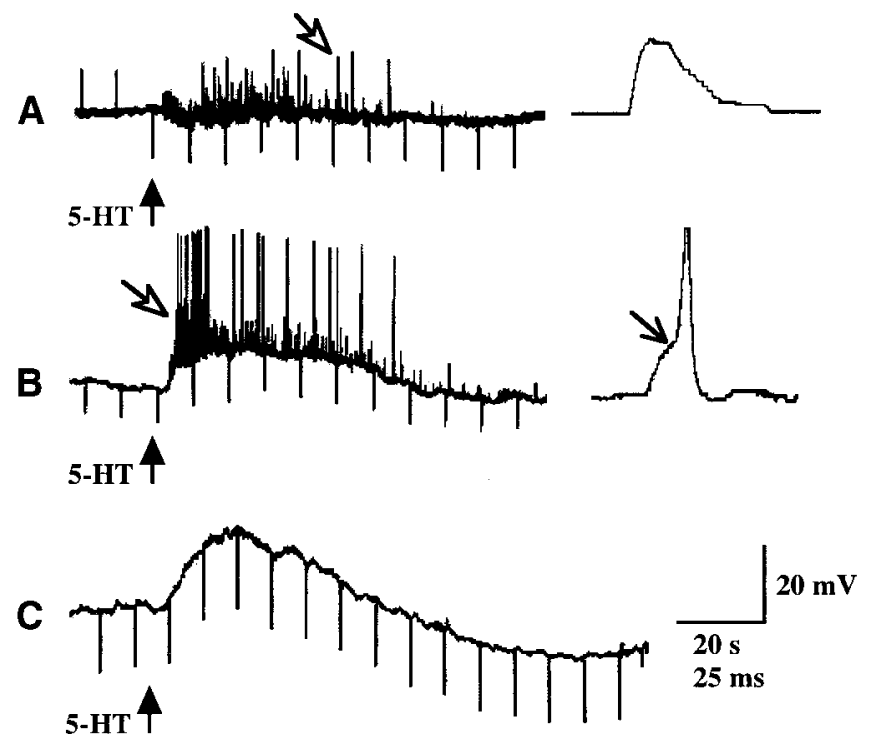

Figure 2. Responses of impaled submucosal neurons to the mucosal application of 5-HT. 5-HT was applied to the intact central strip of mucosa (see Fig. 1) by ejection from a micropipette $(\uparrow)$. The records also show electrotonic potentials to intracellular injection of depolarizing or hyperpolarizing current pulses. $A$, Depolarizing current was injected into cells until the mucosa was stimulated with 5-HT. After stimulation, hyperpolarizing current was injected. A response consisted of a train of fast excitatory potentials (open arrow). B. Mucosal 5-HT elicits a prolonged depolarizing response superimposed on which are fast excitatory potentials (open arrow). During the slow depolarization the neuron is irritable and discharges action potentials that arise from the fast excitatory events $(\searrow)$. $C$, Mucosal 5-HT elicits a prolonged depolarizing response with no associated fast excitatory potentials. The amplitude of the electrotonic potentials is increased during the slow response, indicating that input resistance is increased.

included hCGRP (Calbiochem, San Diego, CA) and its antagonist hCGRP $_{8-37}$ (Peninsula Laboratories, Belmont, CA).

Statistics. Unless noted otherwise, all data are given as means $\pm \mathrm{SE}$. Student's $t$ test was used to compare differences between means. For nonelectrophysiological experiments, the $N$ values refer to the number of experiments and thus also to the number of animals because only one preparation was obtained from each guinea pig. For the electrophysiological studies, the $N$ values refer to the number of neurons, which also is equivalent to the number of preparations. In general, only one preparation was prepared from a single guinea pig, except when cells could not be impaled in that preparation. When such a failure occurred, additional preparations from the original animal were used until a successful impalement was obtained.

\section{RESULTS}

\section{Second-order submucosal neurons are activated after mucosal applications of 5-HT}

Intracellular recordings were obtained from a total of 168 submucosal neurons. All were classified as type I/S neurons (Evans et al., 1994; Cunningham et al., 1997). The mean resting membrane potential was $62 \pm 1 \mathrm{mV}$, and the input resistance was $209 \pm 7$ $\mathrm{M} \Omega$. 5-HT itself was initially used to stimulate the mucosa to isolate the neural component of the response from the release of endogenous 5-HT from EC cells. The effects of stimulating the mucosa with 5-HT (ejected from the tip of a micropipette) were analyzed in 95 neurons. Of these, $75(79 \%)$ responded to the mucosal application of 5-HT (Fig. 2). Both fast and slow excitatory potentials were encountered after the mucosal application of 5-HT. Fast potentials occurred by themselves (Fig. $2 A$ ) and as a component of a mixed response in combination with slow poten-

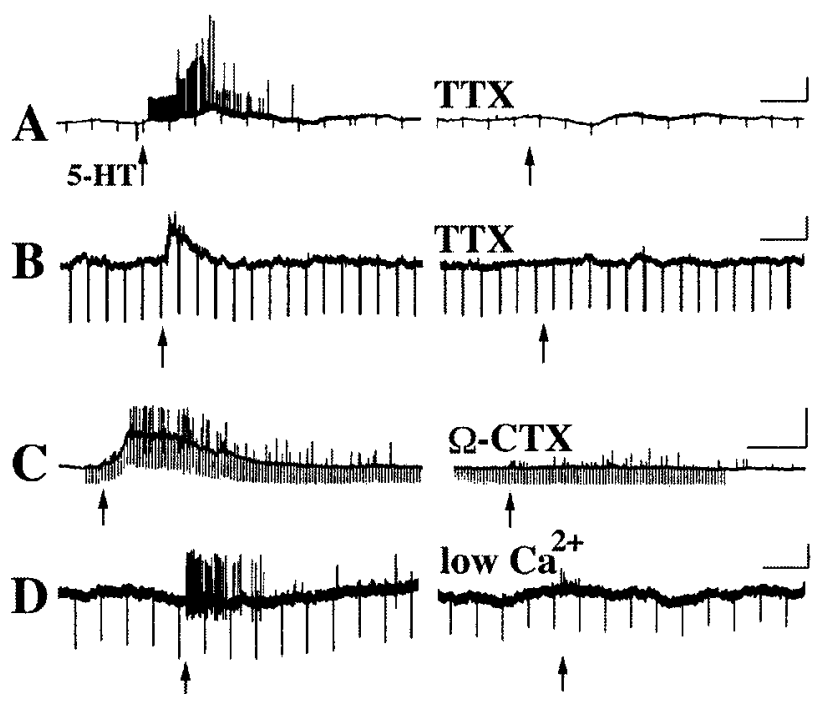

Figure 3. Fast and slow excitatory potentials recorded in submucosal neurons after the mucosal application of 5-HT are blocked by tetrodotoxin $(T T X)$, w-conotoxin $(\Omega-C T X)$, and low $\mathrm{Ca}^{2+} / \mathrm{high} \mathrm{Mg}^{2+}$ containing media. $A$, Fast excitatory potentials evoked by the mucosal application of 5-HT $(\uparrow)$ are blocked by TTX. $B$, A prolonged (slow) excitatory potential evoked by the mucosal application of 5-HT $(\uparrow)$ is blocked by TTX. $C$, Both the prolonged (slow) excitatory potential and the superimposed fast excitatory potential are inhibited by $\Omega$-CTX. The inhibition of fast potentials is incomplete. $D$, Fast excitatory potentials and action potentials are abolished by superfusion with $\mathrm{Ca}^{2+} /$ high $\mathrm{Mg}^{2+}$ containing media. Calibration: $20 \mathrm{sec}, 20 \mathrm{mV}$.

tials (Fig. 2B). Isolated slow excitatory potentials were also observed (Fig. 2C). No inhibitory potentials were seen. The fast excitatory potential had a mean amplitude of $5 \pm 1 \mathrm{mV}$ and a mean duration of $28 \pm 2 \mathrm{msec}$. Bursts of fast potentials (alone or together with slow potentials) were seen in 61 cells $(81 \%)$. Slow excitatory potentials, with a mean amplitude of $8 \pm 1 \mathrm{mV}$ and duration of $98 \pm 11 \mathrm{sec}$, were encountered in 35 (47\%) neurons. Slow excitatory potential were usually associated with an increase in input resistance. The most common response, consisting only of fast potentials, was seen in $40(53 \%)$ cells. Slow potentials occurred without detectable fast potentials in $14(19 \%)$ cells. Both fast and slow excitatory potentials were encountered in 21 (28\%) neurons.

Experiments were performed to determine whether the fast and slow potentials evoked in submucosal neurons by the application of 5-HT to the mucosa were synaptic responses. Fast and slow excitatory potentials were each blocked by $1.0 \mu \mathrm{M}$ tetrodotoxin (Fig. $3 A, B)(n=8)$, suggesting that nerve conduction was necessary for their generation. Fast and slow responses were also inhibited by $0.1 \mu \mathrm{M} \omega$-conotoxin (Fig. $3 C)(n=3)$ and by superfusion with low $\mathrm{Ca}^{2+} /$ high $\mathrm{Mg}^{2+}$-containing media (Fig. $3 D$ ) $(n=3)$, indicating that both responses depended on the release of a neurotransmitter. These observations also imply that the 5-HT applied to the mucosa did not directly affect the neuron impaled at the recording site. If 5-HT had directly affected these cells, then tetrodotoxin, $\omega$-conotoxin, or low $\mathrm{Ca}^{2+} /$ high $\mathrm{Mg}^{2+}$ would not have inhibited the induced depolarizations. Further confirmation that mucosally applied 5-HT did not directly affect neurons in the submucosal ganglia from which recordings were made was obtained in seven preparations in which the impaled submucosal neuron did not respond to the mucosal application of 5-HT (Fig. 4). After the failure of the cell to respond to mucosal 5-HT 

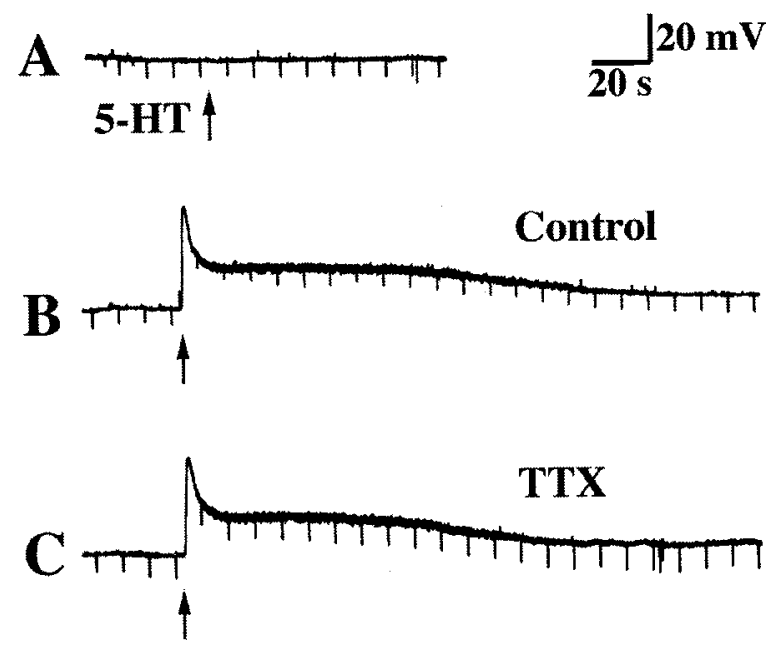

Figure 4. Mucosally applied 5-HT does not exert direct effects on impaled submucosal neurons. $A$, The impaled neuron does not respond to the mucosal application of 5-HT $(\uparrow) . B$, The same neuron does respond to the direct application of 5-HT to its surface $(\uparrow)$. The response is biphasic and consists of an initial fast response, during which input resistance is decreased, and a following prolonged (slow) response, during which input resistance is increased. $C$, Neither component of the direct response to 5-HT is inhibited by TTX.

(Fig. 4A), the stimulating electrode was repositioned close to the impaled neuron, and 5-HT was again applied by microejection using identical parameters of pressure and duration. All seven submucosal neurons responded to the direct microejection of 5-HT with a biphasic response, consisting of an initial transient fast depolarization associated with a decrease in input resistance followed by a more slowly developing but much longer-lived depolarization during which the input resistance usually increased (Fig. 4B). The mean amplitude of the fast response was $18 \pm 5 \mathrm{mV}(n=4)$ and that for the slow depolarization was $21 \pm$ $2 \mathrm{mV}(n=4)$. In contrast to the response of submucosal neurons to mucosal 5-HT, both components of the direct response to 5-HT were resistant to inhibition by tetrodotoxin (Fig. 4C) $(n=$ 7). As a final control, the mucosa was removed and put back in place before 5-HT was applied to it. When neural connections to the mucosa were thus severed, no submucosal neurons ever responded to the mucosal application of 5-HT (data not shown). It was concluded that mucosally applied 5-HT did not affect impaled submucosal neurons directly, but instead stimulated mucosal sensory nerves, evoking fast and/or slow EPSPs in the impaled cells.

Experiments were performed to determine whether one or multiple synapses intervened between the mucosal site of stimulation and the neuron from which recordings were obtained. The impaled submucosal neurons were marked by injection of Neurobiotin through the recording pipette after recordings were obtained. Neurons with axons in the vicinity of the stimulation site were labeled in 10 preparations by implanting glass beads coated with DiI into the mucosa where mucosal stimuli had been applied. After time was allowed to permit DiI to label neurons in the retrograde direction, Neurobiotin was visualized simultaneously with DiI (Fig. 5). The site of stimulation was DiI-labeled and readily identified (Fig. $5 A$ ). DiI-labeled axons projecting into the site and a subset of adjacent neurons could be discerned (Figs. $5 A, B)$, although the intense labeling of the area in which the beads were embedded obscured underlying tissue. No neurons were doubly labeled by DiI and Neurobiotin, suggesting that the neurons impaled at the recording site did not project to the site of stimulation (Fig. $5 C, D$ ). In contrast, careful focusing through the tissue revealed that close contacts were always present between varicose DiI-labeled axons and the Neurobiotin-labeled cells from which recordings were obtained (Fig. $5 D$ ). These observations are consistent with the idea that intrinsic neurons labeled by DiI at the stimulation site project to neurons at the recording site. If so, then the events recorded in the impaled neurons would be monosynaptic.

To verify the suggestion from the morphological observations that a single synapse intervened between the stimulus and recording sites, mucosal nerves were stimulated electrically, rather than with 5-HT, so as to be better able to measure the stimulusresponse delay. Focal electrical stimulation ( $0.5 \mathrm{msec}$ pulse duration), applied to the mucosa, evoked fast EPSPs in 10 of 12 impaled submucosal neurons (Fig. 6). These responses were abolished by tetrodotoxin $(1.0 \mu \mathrm{M})$ (Fig. $6 A)$ and by hexamethonium $(100 \mu \mathrm{M})$ (Fig. $6 B)$. In two of these cells, each EPSP was followed by an IPSP (data not shown). The remaining two cells of the sample responded to focal electrical stimulation of the mucosa only with IPSPs. For EPSPs, the mean amplitude was $9 \pm 1 \mathrm{mV}$ and the duration was $79 \pm 9 \mathrm{msec}(n=10)$. For IPSPs, the mean amplitude was $5 \pm 1 \mathrm{mV}$ and the duration was $291 \pm 8 \mathrm{msec}(n=$ 4). Only EPSPs were used for measurements of the stimulusresponse delay because in the experiments described above 5-HT was never seen to evoke an IPSP. The shortest stimulus-response delay was $4 \mathrm{msec}$, the mean was $7.1 \pm 0.5 \mathrm{msec}$, and individual values appeared to be normally distributed around the mean (Fig. $6 C)$. Because the distance from the stimulation to the recording sites was only $\sim 2 \mathrm{~mm}$, most of the time between stimulus and response probably represents the synaptic delay. The relatively small variability in the duration of the delay and its normal distribution around a single mean are consistent with the idea that the signal traverses only one synapse. To further test the idea that only a single synapse intervenes between the impaled neurons and the primary afferent cells that respond to mucosal stimulation, mucosal stimulation was repeated in media containing high concentrations of $\mathrm{Ca}^{2+}(7.5 \mathrm{~mm})$ and $\mathrm{Mg}^{2+}(8.0 \mathrm{~mm})$. $\left(\mathrm{Na}^{+}\right.$was reduced to maintain osmolality; no affect on spikes was observed.) This medium did not alter responses to mucosal stimulation. In the presence of high concentrations of divalent cations (Vinay et al., 1995), EPSPs can still be elicited in follower cells, but the threshold for eliciting action potentials is raised. As a result, the high $\mathrm{Ca}^{2+} /$ high $\mathrm{Mg}^{2+}$ medium has no effect on monosynaptic responses, but polysynaptic transmission is inhibited. Taken together, these observations suggest that the primary afferent neurons activated by the mucosal application of 5-HT or electrical stimulation evoke fast and/or slow EPSPs in impaled second-order follower cells.

\section{Mucosal application of 5-HT activates submucosal primary afferent neurons via $5-\mathrm{HT}_{1 \mathrm{P}}$ receptors}

The $5-\mathrm{HT}_{1 \mathrm{P}}$ receptor has previously been linked to the activation of submucosal neurons (Kirchgessner et al., 1992, 1996; Chen et al., 1998). It has also been shown to be responsible for 5-HTmediated synaptic responses (myenteric slow EPSPs) (Takaki et al., 1985b; Wade et al., 1994) and associated with peristaltic (Grider et al., 1996; Wade et al., 1996) and secretory (Sidhu and Cooke, 1995; Cooke et al., 1997) reflexes. We thus tested the hypothesis that the $5-\mathrm{HT}_{1 \mathrm{P}}$ receptor mediates the activation of submucosal primary afferent neurons by mucosally applied 5-HT. 
Figure 5. Processes of neurons that project to the mucosal site of stimulation make close contacts with impaled submucosal neurons. After intracellular records were obtained from impaled submucosal neurons, the cells were marked by intracellular injection of Neurobiotin. The preparations were then fixed, and DiIcoated beads were inserted into the mucosa at the site that had been stimulated. After time was allowed for retrograde flow of DiI, Neurobiotin was demonstrated with FITC-labeled streptavidin. $A$, The site of stimulation is marked by the red fluorescence of DiI. Labeled axons (A) leading to labeled nerve cell bodies $(\rightarrow)$ can be seen at the periphery of the site. $B$, At higher magnification, DiI can be seen to have labeled a number of neurites and nerve cell bodies. $C, \mathrm{~A}$ neuron marked by the intracellular injection of Neurobiotin (filter set for FITC fluorescence). $D$, The same cell visualized with a filter that passes both the green fluorescence of FITC and the red fluorescence of DiI. The impaled neuron has not been labeled by DiI, but it is contacted by a DiI-labeled varicose nerve fiber. Scale bars: $A, B, 100 \mu \mathrm{m} ; C, D, 25 \mu \mathrm{m}$.
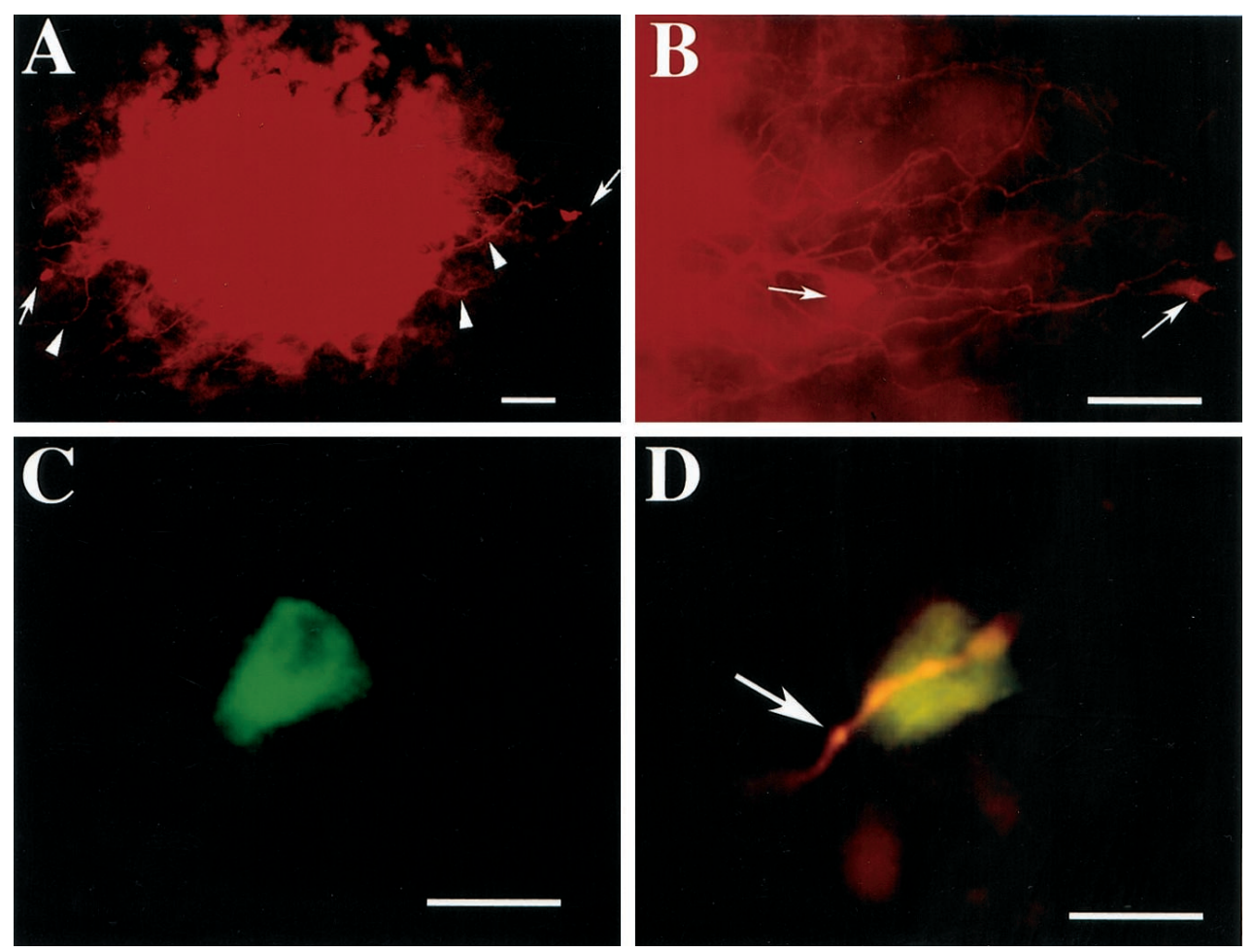

The specific 5-HT ${ }_{1 \mathrm{P}}$ antagonist, 5-HTP-DP (Takaki et al., $1985 \mathrm{a}$ ), was used to test the hypothesis that $5-\mathrm{HT}_{1 \mathrm{P}}$ receptors mediate the activation of primary afferent neurons after the stimulation of the mucosa with 5-HT. A micropipette was positioned to apply 5-HT to the mucosal surface of the bowel, and submucosal neurons were impaled as described above. Control responses were obtained, and after consecutive applications of 5-HT elicited responses (fast and/or slow EPSPs) of the same amplitude, the preparations were superfused with a solution containing $10 \mu \mathrm{M}$ 5-HTP-DP. The inclusion of 5-HTP-DP in the superfusing solution did not itself alter the membrane potential. Stimulation of the mucosa with 5-HT was repeated in the presence of 5-HTP-DP. In five of eight preparations, superfusion with 5-HTP-DP inhibited both the fast (Fig. 7A) and slow (Fig. 7B) EPSPs evoked in submucosal neurons by mucosal application of 5-HT. The effect of 5-HTP-DP was slowly reversible. Mucosal applications of WAY 100325, a substituted benzamide that acts as an agonist at 5- $\mathrm{HT}_{1 \mathrm{P}}$ receptors (Wade et al., 1993), mimicked the effects of 5-HT, eliciting both fast and slow EPSPs (Fig. 7C) $(n=$ $3)$. The preparations that responded to WAY 100325 also responded to 5-HT; those preparations that did not respond to 5-HT also did not respond to WAY $100325(n=4)$. When added to the superfusing solution, WAY 100325 evoked a long-lasting slow depolarization (amplitude $20 \mathrm{mV}$ ) of submucosal neurons (data not shown).

Tropisetron was used to test the possibility that $5-\mathrm{HT}_{3}$ or $5-\mathrm{HT}_{4}$ receptors contribute to the activation of submucosal primary afferent neurons by 5-HT. At concentrations below $1 \mu \mathrm{M}$, tropisetron is $5-\mathrm{HT}_{3}$-selective, but at concentrations $\geq 1 \mu \mathrm{M}$, tropisetron also inhibits 5- $\mathrm{HT}_{4}$ receptors (Bockaert et al., 1990; Kadowaki et al., 1996). Neither concentration of tropisetron affects $5-\mathrm{HT}_{1 \mathrm{P}}$ receptors in the myenteric plexus (Wade et al., 1994; Pan et al., 1997), although tropisetron has been found to prevent the activation of enteric reflexes in response to mucosal 5-HT (Grider et al., 1996). Tropisetron, at concentrations below
Control
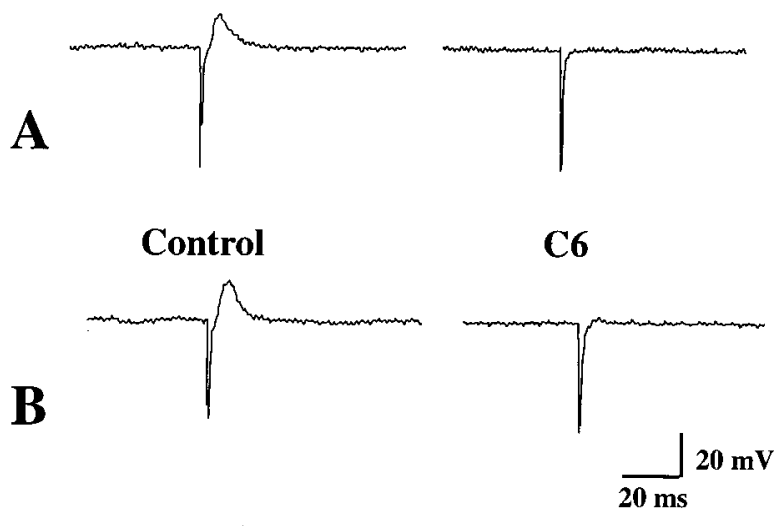

C

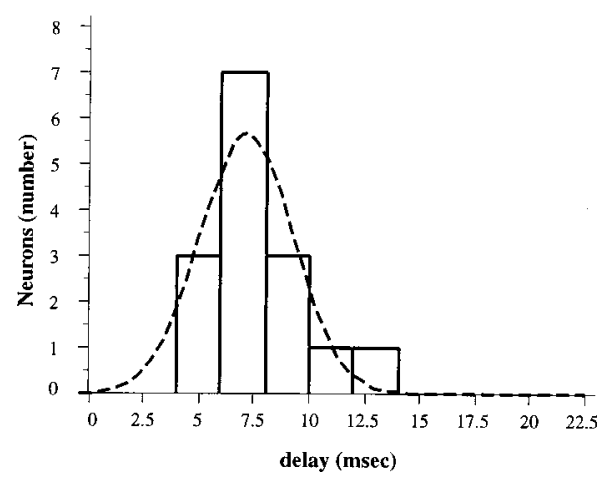

Figure 6. Fast EPSPs evoked in a submucosal neuron by focal electrical stimulation directed at the mucosa. $A$, The fast EPSP is blocked by TTX. $B$, The fast EPSP is blocked by hexamethonium and thus is cholinergic and mediated by nicotinic receptors. $C$, A histogram is plotted showing the stimulus-response delay for fast EPSPs evoked in submucosal neurons by electrical stimulation of the mucosa. 


\section{Control 5-HTP-DP}
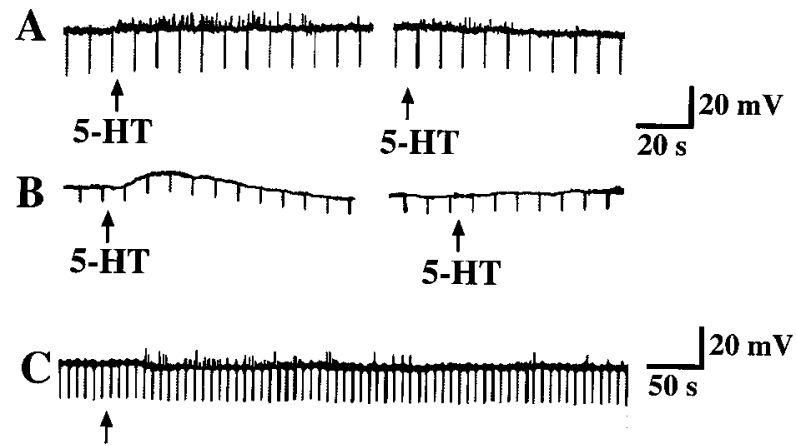

Way 100325

Figure 7. Fast and slow EPSPs evoked in submucosal neurons by the mucosal application of 5-HT are mediated by $5-\mathrm{HT}_{1 \mathrm{P}}$ receptors. $A$, Fast EPSPs evoked by the mucosal application of 5-HT are inhibited by the 5 -HT 1 P antagonist 5-HTP-DP. B, A slow EPSP evoked by the mucosal application of 5-HT is inhibited by 5-HTP-DP. $C$, Application of the $5-\mathrm{HT}_{1 \mathrm{P}}$ agonist WAY100325 to the mucosa evokes fast EPSPs in a submucosal neuron.
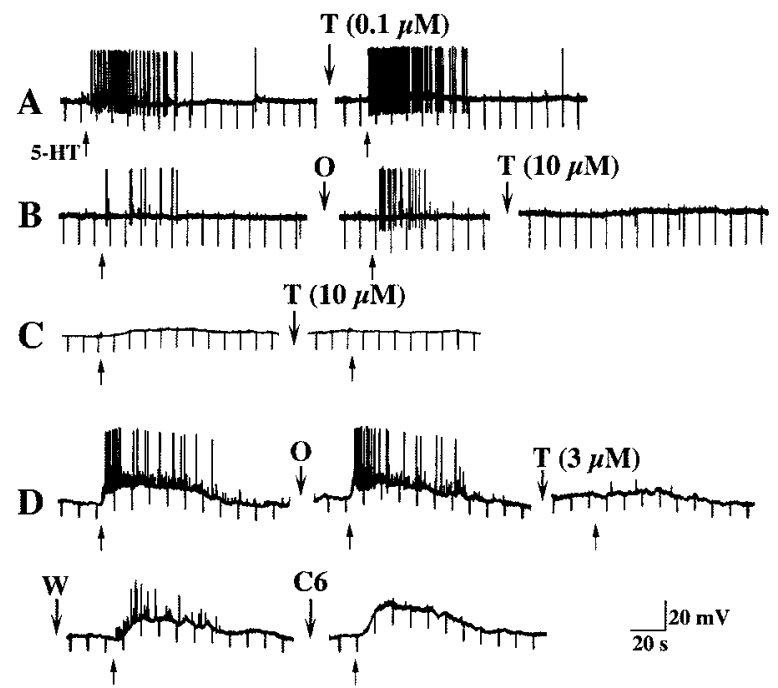

Figure 8. Responses of submucosal neurons to mucosal applications of 5 -HT are not inhibited by antagonism of $5-\mathrm{HT}_{3}$ receptors but are antagonized by high concentrations of tropisetron. Responses of four cells $(A-D)$ from different animals are illustrated. $A$, Fast EPSPs and an associated burst of action potentials are evoked by mucosal application of 5-HT $(\uparrow)$. These responses are not inhibited by $0.1 \mu \mathrm{M}$ tropisetron $(T)$. $B$, In another cell, fast EPSPs and associated action potentials are evoked by mucosal application of 5-HT $(\uparrow)$. These responses are not inhibited by $1 \mu \mathrm{M}$ ondansetron $(O)$, but they are abolished by tropisetron $(10 \mu \mathrm{M}) . C$, A slow EPSP is evoked in a submucosal neuron by mucosal 5-HT $(\uparrow)$. This response is blocked by $10 \mu \mathrm{M}$ tropisetron. $D$, Mucosal 5-HT ( $\uparrow$ ) elicits a prolonged slow EPSP superimposed on which are fast EPSPs and associated action potentials. Neither the fast nor the slow EPSPs are inhibited by ondansetron $(O)$, but they are reversibly inhibited by a high concentration of tropisetron $(3 \mu \mathrm{M})$. After the washout of tropisetron $(W)$, both fast and slow EPSPs return. Fast but not slow EPSPs are abolished by hexamethonium (C6).

$1 \mu \mathrm{M}$, failed to affect responses to mucosal stimulation with 5-HT (Fig. 8A). Ondansetron $(1 \mu \mathrm{M})$, a more selective $5-\mathrm{HT}_{3}$ antagonist than tropisetron, also failed to affect responses to mucosal application of 5-HT (Fig. $8 B, D)(n=4)$. Despite the addition of ondansetron, fast EPSPs continued to be evoked by mucosal
Table 2. Responses of submucosal neurons to mechanical stimulation of the mucosa

\begin{tabular}{lllll} 
& $\begin{array}{l}\text { Fast } \\
\text { EPSP }\end{array}$ & $\begin{array}{l}\text { Slow } \\
\text { EPSP }\end{array}$ & $\begin{array}{l}\text { Fast }+ \\
\text { slow EPSP }\end{array}$ & $\begin{array}{l}\text { No } \\
\text { response }\end{array}$ \\
\hline Number of cells & 2 & 29 & 3 & 24 \\
$\%$ of total $(n=58)$ & 3 & 50 & 5 & 42 \\
\hline
\end{tabular}

application of 5-HT, and slow EPSPs were unchanged in amplitude (control $=13 \pm 2 \mathrm{mV}$; ondansetron $=12 \pm 2 \mathrm{mV} ; n=4$ ). These data suggest that $5-\mathrm{HT}_{3}$ receptors do not contribute to the activation of submucosal neurons by mucosally applied 5-HT. In contrast, at concentrations $\geq 1 \mu \mathrm{M}$, tropisetron reproducibly inhibited both fast (Fig. $8 B, D)$ and slow (Fig. $8 C, D)$ EPSPs $(n=7)$. The effect of tropisetron was reversible (Fig. $8 D$ ). Fast, but not slow, EPSPs were blocked by hexamethonium $(100 \mu \mathrm{M})$ (Fig. $8 D)$ $(n=8)$. Although the action of tropisetron is consistent with antagonism of $5-\mathrm{HT}_{4}$ receptors, the $5-\mathrm{HT}_{4}$-selective antagonists SB-204070 (1 $\mu \mathrm{M} ; n=2)$ and GR-113808 (1 $\mu \mathrm{M} ; n=2)$, failed to affect responses of submucosal neurons to the mucosal application of 5-HT. The 5-HT 4 agonist BIMU-8 (1 mM; $n=6)$ also failed to elicit responses in submucosal neurons that responded to the mucosal application of 5-HT.

\section{Responses of submucosal neurons to mechanical stimulation of the mucosa}

The responses of submucosal neurons to mechanical stimulation of the mucosa were assessed and compared with those elicited by mucosally applied 5-HT. To stimulate the mucosa mechanically, single or multiple puffs of $\mathrm{N}_{2}$ were directed at the mucosal surface from a glass micropipette to minimize the area of perturbation. Alternatively, pressure was applied to the intact mucosa, either with a blunt glass micropipette or with a similar pipette the tip of which was coated with a sponge. The most consistent results were obtained with the blunt glass pipette. The pipette was lowered under visual control until just short of the tip of a villus, after which a piezoelectric motor-driven micromanipulator was used to lower the pipette by $200 \mu \mathrm{m}$ in $10 \mu \mathrm{m}$ steps. The pipette was allowed to apply pressure to the mucosal surface for $10-20 \mathrm{sec}$ and then was raised. Thirty-four of 58 impaled submucosal neurons $(59 \%)$ responded to these stimuli (Table 2 ). Three types of response were obtained: slow EPSPs (Fig. 9A), which averaged $11 \pm 1 \mathrm{mV}$ in amplitude and $121 \pm 20 \mathrm{sec}$ in duration $(n=32)$, fast EPSPs (Fig. 9B), which averaged $7 \pm 2 \mathrm{mV}$ in amplitude $(n=$ 5 ), and mixed responses, consisting of both fast and slow EPSPs. Slow EPSPs were observed more commonly than fast EPSPs or mixed responses (Table 2). In two cells, which were not averaged with the remainder, a slow EPSP was elicited by mechanical stimulation with a glass pipette that lasted for $>10 \mathrm{~min}$.

To test the effect of 5-HTP-DP or tropisetron on the fast and slow EPSPs evoked in submucosal neurons by mechanical stimulation of the mucosa, control responses were obtained first in the absence of the compounds (Fig. 9A,B). Stimulation was then repeated after the application of $10 \mu \mathrm{M}$ 5-HTP-DP or $1 \mu \mathrm{M}$ tropisetron and again after the washout of these compounds. 5-HTP-DP and tropisetron each inhibited both the fast and slow EPSPs evoked in submucosal neurons by mechanical stimulation of the mucosa (Fig. 9B) $(n=7)$. Neither 5-HTP-DP nor tropisetron altered the membrane potential in any of the cells examined.

5-HT was applied to the mucosal surface in six preparations that contained submucosal neurons in which slow EPSPs were 

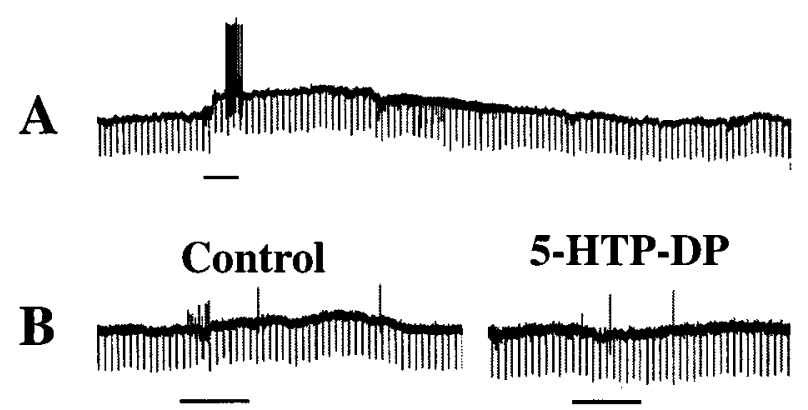

\section{5-HTP-DP}
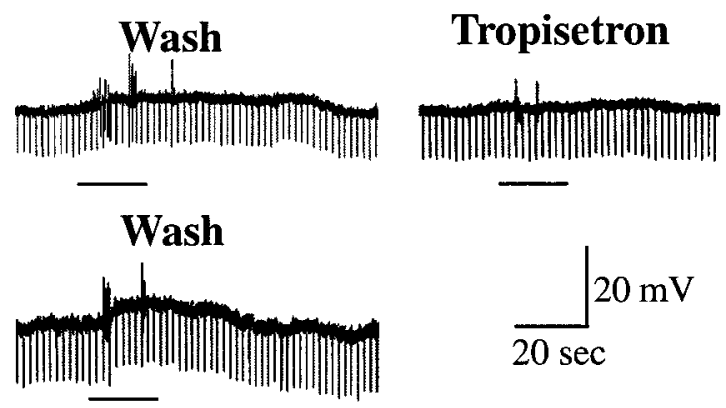

Figure 9. Fast and slow EPSPs evoked in submucosal neurons by mechanical stimulation of the mucosa are mediated by $5-\mathrm{HT}_{1 \mathrm{P}}$ receptors. $A$, A prolonged slow EPSP is evoked in a submucosal neuron by application of a mechanical stimulus to the mucosa (underline). The neuron becomes excited during the response and discharges a burst of action potentials. $B$, In a different preparation from another animal, a small slow EPSP and bursts of fast EPSPs are evoked by the delivery of a mechanical stimulus (underline) to the mucosa. Both slow and fast EPSPs are reversibly inhibited by 5-HTP-DP. Both slow and fast EPSPs recover after the washout of 5-HTP-DP. The responses are then reversibly inhibited by tropisetron $(1 \mu \mathrm{M})$ and again recover after the washout of the drug.

evoked by puffs of $\mathrm{N}_{2}$ directed at the mucosal surface and in five additional preparations in which neurons failed to respond to the delivery of similar stimuli. 5-HT was ejected from the tip of a micropipette positioned as closely as possible to the site that had previously been stimulated with $\mathrm{N}_{2}$. Slow EPSPs, identical to those evoked by $\mathrm{N}_{2}$ puffs, were elicited by 5 -HT in four of the six neurons that had previously responded to $\mathrm{N}_{2}$ puffs. Fast EPSPs were also seen in one of these four neurons, although fast EPSPs had not earlier been evoked in that cell by mechanical stimulation. Mucosal applications of 5-HT were found to evoke fast EPSPs in four of the five cells that did not respond when the mucosa was previously stimulated with puffs of $\mathrm{N}_{2}$. These observations suggest that a greater number of primary afferent neurons are stimulated by exogenous 5-HT diff using through the mucosal epithelium than by endogenous 5-HT released from the limited number of EC cells stimulated by a highly localized mechanical stimulus.

\section{Identification of the neurotransmitter(s) used by submucosal primary afferent neurons}

Electrophysiological studies were undertaken to identify the transmitter(s) used by the primary afferent neurons. These studies were based on the evidence (described above) that responses recorded in impaled neurons after mucosal stimulation are monosynaptic. The resultant EPSPs in the second-order cells must thus be generated by the neurotransmitter(s) released from primary afferent neurons. 5-HT was used as the mucosal stimulus, both because it reproducibly activates submucosal primary afferent neurons (see above) and because it stimulates mucosal processes
A
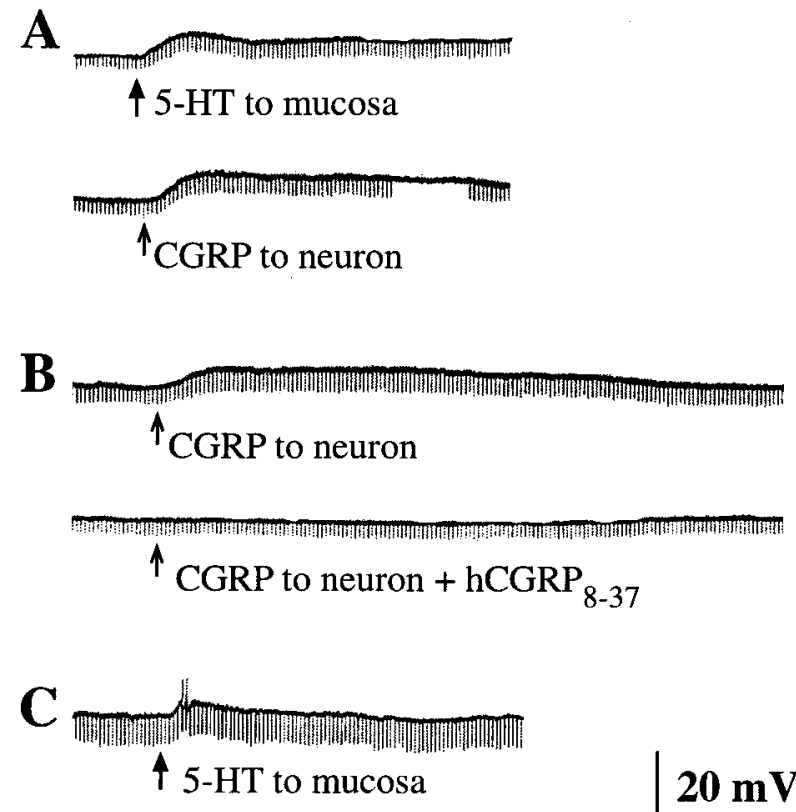

$20 \mathrm{mV}$

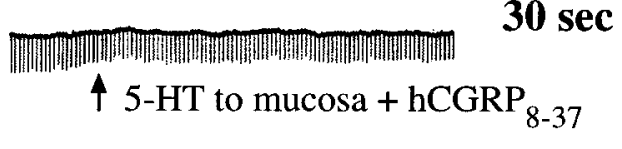

Figure 10. Slow EPSPs evoked by the mucosal application of 5-HT are mediated by CGRP. $A$, The delivery of 5 -HT $(\uparrow)$ to the mucosa elicits a slow EPSP in a submucosal neuron. This response is mimicked by the delivery of CGRP $(\uparrow)$ directly to the surface of the same neuron. $B$, CGRP evokes a slow depolarizing response when applied to a submucosal neuron. This effect is blocked by $\mathrm{hCGRP}_{8-37} . C$, The application of 5-HT $(\uparrow)$ to the mucosa evokes a slow EPSP during which the neuron becomes excitable and discharges action potentials. The response of the cell to the mucosal application of 5-HT is blocked by hCGRP h-37 $_{8}$.

of these cells directly. Responses to 5-HT thus do not depend on the release of a transmitter from epithelial cells.

Hexamethonium $(100 \mu \mathrm{M})$ was found to eliminate all of the fast EPSPs that were evoked by mucosal 5-HT (Fig. 8D). Fast EPSPs are therefore cholinergic and nicotinic. Hexamethonium $(100 \mu \mathrm{M})$ was thus included in the medium to enable the slow EPSPs evoked by mucosal 5-HT to be studied without interference from simultaneously evoked fast EPSPs. The EPSPs recorded in second-order submucosal neurons after the application of 5-HT to the mucosa were mimicked by the direct application of CGRP to four of six impaled cells (Fig. 10A) $(9 \pm 2 \mathrm{mV})$. In contrast, CGRP never elicited a response when it was applied to the mucosal surface (data not shown). The CGRP antagonist hCGRP $_{8-37}(5.0 \mu \mathrm{M})$ blocked the direct effects of CGRP on the impaled neurons (Fig. 10B). hCGRP ${ }_{8-37}$ also blocked the responses of four of seven neurons to the mucosal application of 5-HT (Fig. 10C). When hCGRP ${ }_{8-37}$ failed to block the effects of mucosal applications of 5-HT (three of seven cells), the impaled neurons were also nonresponsive to the direct application of CGRP (Fig. 11). These observations are compatible with the idea that a subset of the primary afferent neurons stimulated by mucosally applied 5-HT use CGRP as a cotransmitter with ACh. The neurons that continue to exhibit slow EPSPs in the presence of the CGRP antagonist probably use a slow transmitter other than CGRP. The muscarinic antagonist scopolamine $(1.0 \mu \mathrm{M}$, a concentration adequate to block muscarinic responses to $\mathrm{ACh}$ ) antagonized the slow response to 5-HT in 1 of 10 neurons. 


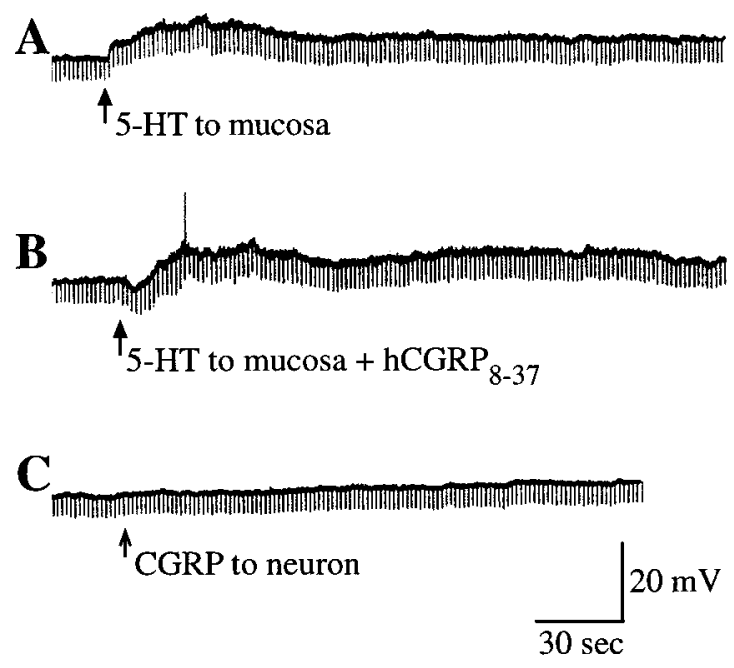

Figure 11. A subset of the slow EPSPs evoked in submucosal neurons by mucosally applied 5-HT is not mediated by CGRP. $A$, The application of 5-HT ( $\uparrow)$ to the mucosa elicits a slow EPSP in a submucosal neuron. $B$, This response is not inhibited by hCGRP $_{8-37}$. $C$, The same neuron is unresponsive to the direct application of CGRP to its surface.

Responses to mucosal applications of 5-HT were not inhibited by an NMDA antagonist $[( \pm)]$-CPP $(50 \mu \mathrm{M})](n=3)$ or by mixtures of $\mathrm{NK}_{1}$ (Win 51708), $\mathrm{NK}_{2}$ [GR94800 $(2.0 \mu \mathrm{M})$ and Men 10376 $(2.0 \mu \mathrm{M})]$, and $\mathrm{NK}_{3}[\mathrm{NK} 4-10(1.0 \mu \mathrm{M})]$ receptor antagonists $(n=10)$.

The hypothesis that CGRP is a transmitter of submucosal primary afferent neurons was tested further by determining the number of neurons activated by mucosal stimulation under various experimental conditions. Activated neurons were identified either by detecting their uptake of FM2-10 in surviving preparations (Kirchgessner et al., 1996; Chen et al., 1998) or by immunocytochemically detecting the expression of the proto-oncogene c-fos in fixed tissue (Kirchgessner et al., 1992). Mechanical stimuli were applied in vitro by gently stroking the intact villus surface of segments of bowel in the presence of FM2-10. Uptake of FM2-10 by enteric neurons, after application of pressure to the intestinal mucosa, is blocked by TTX and thus depends on neuronal activity (Kirchgessner et al., 1996). Stroking the mucosa greatly increased the number of neurons that took up FM2-10 (Fig. 12). This effect was inhibited when stroking was performed in the presence of the CGRP antagonist, hCGRP ${ }_{8-37}(5.0 \mu \mathrm{M})$. Very little neuronal uptake of FM2-10 occurred in the control segments of gut that were not stroked, suggesting that there may be little spontaneous neuronal activity in submucosal ganglia in vitro. Similar data were obtained by examining Fos immunoreactivity. In this case, however, puffs of $\mathrm{N}_{2}$ were delivered to the villus surface for $30 \mathrm{~min}$. Stroking was not used for stimulation because it was thought that 30 min of stroking might damage the mucosa. Almost no neurons were Fos-immunoreactive in the nonstimulated control segments of bowel (Fig. 13A). Stimulation of the mucosa caused Fos immunoreactive nuclei to appear in those submucosal ganglia that were located within $\sim 4 \mathrm{~mm}$ of the mucosal site perturbed by the stimuli (Fig. 13B). When stimulation was performed in the presence of hCGRP ${ }_{8-37}(5.0 \mu \mathrm{M})$, almost no Fos-immunoreactive neurons could be detected anywhere in the preparations (Fig. 13C).

Because pharmacological experiments suggested that CGRP is a transmitter of submucosal primary afferent neurons, experiments were performed to determine whether a subset of CGRP-

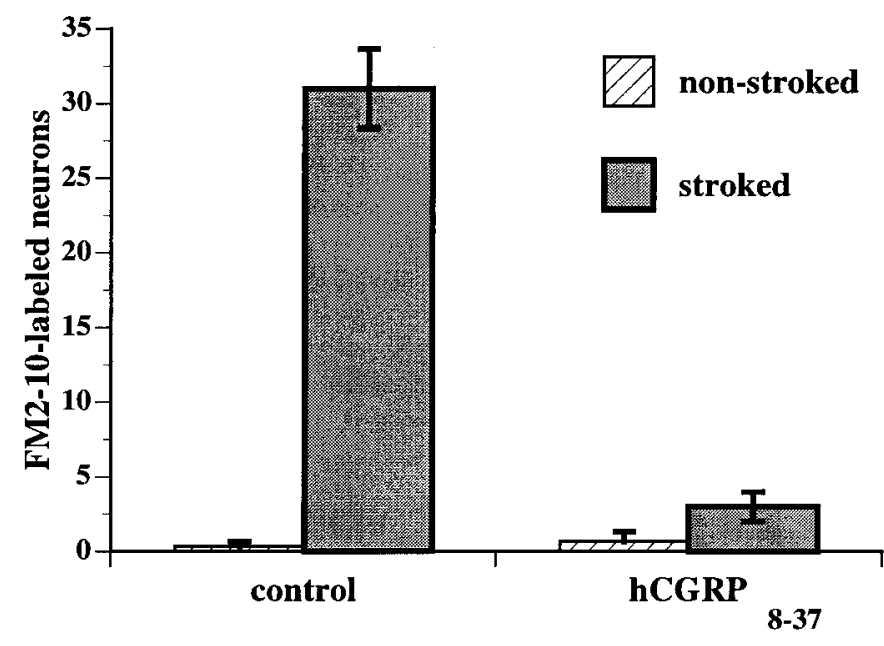

Figure 12. Analysis of the uptake of the activity probe FM2-10 suggests that CGRP-mediated neurotransmission is necessary for the spread of excitation in the submucosal plexus after the delivery of a mechanical stimulus (stroking) to the mucosa. The intact mucosal surface was gently stroked to activate submucosal primary afferent neurons counted in surviving preparations of mucosa-submucosa. FM2-10 was present and used as a neuronal activity probe. The number of submucosal neurons taking up FM2-10 was determined in nonstroked and stroked regions. Under control conditions, the number of neurons taking up FM2-10 was greatly increased by stroking the mucosa. The effect of stroking was blocked by the CGRP antagonist hCGRP $_{8-37}$.

containing neurons is actually activated after mucosal stimulation with 5-HT. 5-HT was applied to the mucosa by ejection from the tip of a micropipette, as described previously. FM2-10 was present in the medium to detect activated neurons. The living preparations were then examined to identify cells that had taken up FM2-10. The medium was then changed to one containing DAB, and the preparation was photoconverted in the presence of DAB. The brown DAB reaction product permanently marks the FM2-10 fluorescent cells, so that the activated cells can still be identified after the tissues have been subjected to immunocytochemistry. After photoconversion, the preparations were fixed and immunostained to locate CGRP-immunoreactive submucosal neurons. Coincident localization of CGRP immunoreactivity (Fig. 14A) and the FM2-10/DAB photoconversion reaction product (Fig. 14B) was found in some but not all CGRPimmunoreactive neurons. CGRP immunoreactivity was not observed in all of the cells that contained the FM2-10/DAB photoconversion reaction product. These observations suggest that mucosal application of 5-HT activates a subset rather then the whole set of CGRP-containing neurons and that the activated CGRP-containing cells represent only a subset of the submucosal neurons activated by 5 -HT.

Chronic denervation of a loop of intestine was used to determine whether responses recorded in submucosal neurons could have been mediated by collaterals of extrinsic sensory neurons. Perivascular and paravascular axons were cut surgically, and the blood vessels were then painted with phenol to ensure that all axons had been lesioned (Galligan et al., 1988; Li et al., 1998). To verify that extrinsic fibers were completely lacking from the denervated loops of gut, sympathetic axons were visualized by demonstrating TH immunocytochemically. No TH immunoreactivity was found in either the submucosal or myenteric plexuses of the denervated bowel (Fig. 15B,D), but both plexuses were normally innervated in the nondenervated control loops of gut from 
Figure 13. Analysis of Fos immunoreactivity supports the idea that CGRPmediated neurotransmission is required for the spread of excitation in the submucosal plexus after the delivery of a mechanical stimulus to the mucosa. Puffs of $\mathrm{N}_{2}$ were used to excite submucosal neurons as described previously (Kirchgessner et al., 1992). A, There is no Fos immunoreactivity in the nuclei of the neurons in a submucosal ganglion of a nonstimulated preparation. $B$,
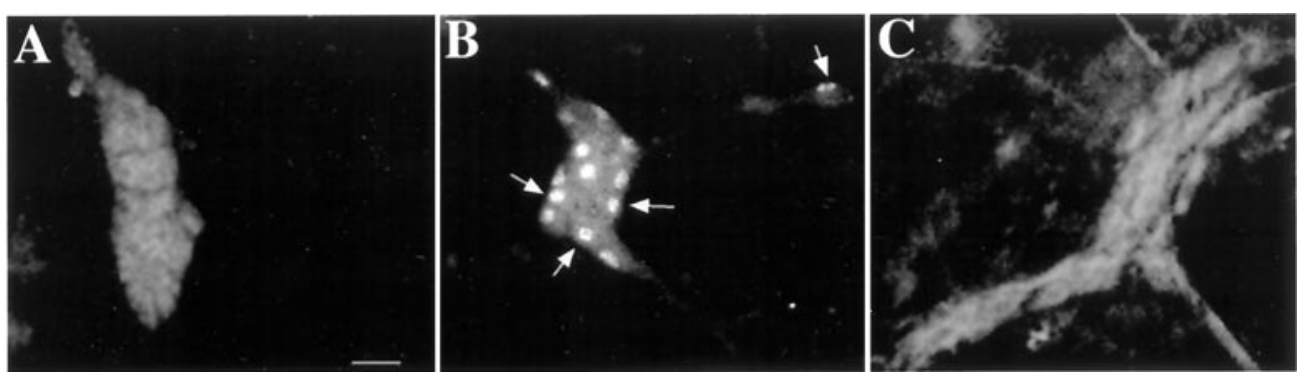

a submucosal ganglion after the mucosa had been stimulated under control conditions with $\mathrm{N}_{2}$ puffs for 30 min. $C$, No Fos-immunoreactive nuclei can be found in submucosal ganglia when the mucosa was stimulated with $\mathrm{N}_{2}$ puffs for 30 min (as in $B$ ) but in the presence of the CGRP antagonist hCGRP $_{8-37}$. Scale bar, $50 \mu \mathrm{m}$.

the same operated animals (Fig. $15 A, C$ ). The absence of $\mathrm{TH}$ immunoreactivity verifies that sympathetic axons, all of which are extrinsic, had degenerated. Sympathetic axons thus served as a surrogate marker for the extrinsic innervation. Extrinsic denervation affected neither the occurrence of fast EPSPs (seen in six of seven neurons in denervated strips from three guinea pigs) nor the occurrence (five of seven neurons) or amplitude of slow EPSPs $(8.6 \pm 1.2 \mathrm{mV} ; n=5$ neurons in denervated strips from three guinea pigs; $p$ is not significant vs control $8 \pm 1 ; n=35$ neurons) evoked by mucosal applications of 5-HT. These data rule out the possibility that extrinsic collaterals were the source of the transmitter responsible for fast or slow EPSPs evoked by mucosal 5-HT in submucosal neurons.

\section{Neuroactive substances found in submucosal neurons that respond to mucosal stimulation by 5-HT}

The mucosa was stimulated with 5-HT (as above) and recordings were made from 37 second-order neurons with Neurobiotin-filled micropipettes. After responses were obtained, the cells were marked by injection with Neurobiotin. The preparations were then fixed and prepared for the immunocytochemical identification of neuroactive substances within the cells. A limitation of the study was that the immunocytochemical investigation was restricted to substances that can be demonstrated in cell bodies without previous treatment of tissue with colchicine. Antibodies were thus chosen to try to relate the data to previous reports that have established the chemical coding of submucosal neurons (Table 3). Immunocytochemical investigation was restricted to cells with clear fast EPSPs or slow EPSPs. Slow EPSPs were obtained in cells that contained CGRP immunoreactivity (Table 3; Fig. 16A-C). Fast EPSPs, however, were not recorded in CGRP-immunoreactive neurons. Fast EPSPs were found in neurons that contained calretinin immunoreactivity (Fig. 16D-F), in cells that were immunostained with antibodies to neuropeptide $\mathrm{Y}$ (NPY), and in neurons that lacked NPY but were dynorphinimmunoreactive (Table 3). Slow EPSPs were not encountered in neurons that were immunostained with antibodies to NPY, dynorphin, or calbindin (Fig. 16G,H; Table 3). In nine preparations, no responses were obtained to mucosal stimulation with 5-HT. In three of these nonresponding preparations, the injected Neurobiotin was found in glia, and in each case the injected Neurobiotin was found to have labeled a network of cells that were evidently dye-coupled (Fig. 16I).

\section{DISCUSSION}

Goals were to confirm that 5-HT released from the mucosa by mechanical stimuli activates submucosal primary afferent neurons, to identify the subtypes of responsible 5-HT receptors, and to identify the neurotransmitter(s) used by primary afferents to stimulate second-order neurons. Responses of submucosal neurons to mucosal stimulation were analyzed in myenteric plexusfree preparations of small intestine \pm extrinsic denervation. Several lines of evidence indicated that recorded responses were fast and slow EPSPs elicited in impaled second-order neurons by the primary afferent neurons stimulated by mucosal 5-HT. Both types of response were blocked by TTX, $\omega$-conotoxin, and low $\mathrm{Ca}^{2+}$ / high $\mathrm{Mg}^{2+}$-containing media, indicating that they required axonal conduction and synaptic transmission. Impaled neurons, marked by intracellular injection of Neurobiotin, were not colabeled by the retrograde flow of DiI from the stimulated region of the mucosa. Instead, they were closely contacted by varicose DiI-labeled axons, suggesting that the primary afferent neurons that projected to the 5-HT-stimulated mucosal site also projected to the impaled neurons. The conclusion that recorded responses were monosynaptic was supported by the relatively small variation in the stimulus-response delay and the lack of effect on EPSPs of media containing a high concentration of divalent cations to inhibit polysynaptic transmission (Vinay et al., 1995). Because submucosal primary afferent neurons were never impaled, they must have small receptive fields and be located immediately underneath the mucosa that they innervate (where ganglia could not be studied). The absence of polysynaptic transmission may be explained by the restriction of the investigation to ganglia that were located $\sim 2 \mathrm{~mm}$ from the stimulus site.

5-HT could not have been the neurotransmitter responsible for either the fast or slow EPSPs recorded in second-order cells after mucosal stimulation. Enteric serotonergic neurons are myenteric and thus are severed by removing the myenteric plexus (Costa et al., 1982; Furness and Costa, 1982). Consequently, 5-HT antagonists must block the response of primary afferent cells to 5-HT to prevent EPSPs in second-order neurons. Four subtypes of 5-HT receptor $\left(5-\mathrm{HT}_{3}, 5-\mathrm{HT}_{4}, 5-\mathrm{HT}_{1 \mathrm{~A}}\right.$, and $\left.5-\mathrm{HT}_{1 \mathrm{P}}\right)$ mediate enteric neuronal responses to $5-\mathrm{HT}$. The $5-\mathrm{HT}_{3}$ receptor mediates fast EPSPs (Mawe et al., 1986), and although no 5- $\mathrm{HT}_{4}$ mediated postsynaptic responses have been observed, the $5-\mathrm{HT}_{4}$ receptor acts presynaptically to increase the release of $\mathrm{ACh}$ (Pan and Galligan, 1994). The 5- $\mathrm{HT}_{1 \mathrm{~A}}$ receptor is inhibitory (Galligan and North, 1991; Pan and Galligan, 1994). The 5-HT $1 \mathrm{P}$ receptor binds 5-HT with high affinity (Branchek et al., 1984), requires that indole ligands have a free hydroxyl moiety (Branchek et al., 1984, 1988; Mawe et al., 1986), and is coupled to $\mathrm{G}_{\mathrm{o}}$ (Wang et al., 1996; Pan et al., 1997). Stimulation of the $5-\mathrm{HT}_{1 \mathrm{P}}$ receptor leads to the activation of protein kinases A and C (Pan et al., 1997).

Both the fast and the slow EPSPs evoked by mucosal 5-HT in second-order neurons were blocked by the $5-\mathrm{HT}_{1 \mathrm{P}}$ antagonist 

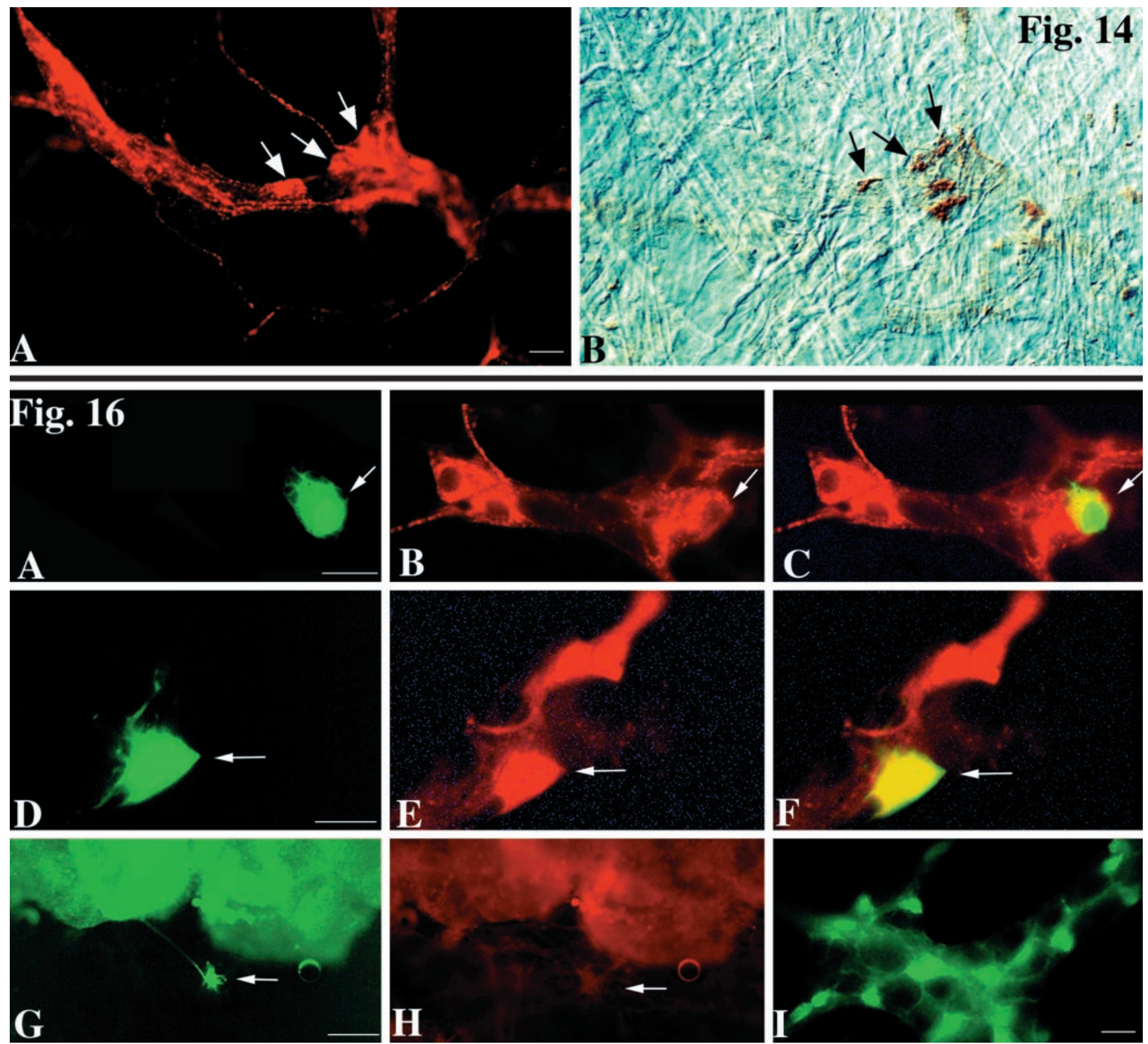

Figure 14. Top. A subset of the submucosal neurons that are induced to take up FM2-10 in response to the mucosal application of 5-HT mucosa contain CGRP. 5-HT was applied to the mucosa in the presence of the activity probe FM2-10. Active neurons were located and illuminated in the presence of DAB to photoconvert FM2-10 fluorescence to an insoluble DAB reaction product. The preparations were then fixed, and CGRP immunoreactivity was demonstrated. $A$, CGRP immunofluorescence. $B$, DAB reaction product visualized in the same field with bright-light and interference contrast optics. The arrows point to doubly labeled cells that contain both CGRP immunoreactivity and the FM2-10 $\rightarrow$ DAB photoconversion reaction product. Scale bar, $20 \mu$ m.

Figure 16. Bottom. Subsets of submucosal cells that did or did not respond to mucosal stimulation with 5-HT were immunocytochemically identified. After intracellular records were obtained and responses of neurons to the mucosal application of 5-HT were determined, the cells were marked by intracellular injection of Neurobiotin through the recording pipette. The preparations were subsequently immunostained. $A-C$, Slow EPSPs were recorded in a neuron that contained CGRP immunoreactivity. The impaled cell thus contains Neurobiotin demonstrated with FITC-streptavidin $(A$, $\swarrow)$. The ganglion in which the impaled cell is located contains several CGRP-immunoreactive cells demonstrated with Cy3 $(B, \swarrow)$. Superimposition of images reveals that the Neurobiotin-marked cell is CGRP-immunoreactive $(C, \swarrow)$. $D-F$, Fast EPSPs were recorded in a neuron that contained calretinin immunoreactivity. The Neurobiotin-marked cell $(D, \leftarrow)$ can be located in a ganglion that contains calretinin-immunoreactive cells $(E, \leftarrow)$ and is confirmed as calretinin-immunoreactive by the superimposition of images $(F, \leftarrow)$. $G, H$, Calbindin immunoreactivity was not observed in a cell from which slow EPSPs were recorded. There is a nonspecific staining of the mucosa shown in $G$ and $H$. The Neurobiotin-marked cell $(G, \leftarrow)$ does not contain calbindin immunoreactivity $(H, \leftarrow)$. I, Cells that do not respond to the mucosal application of 5-HT are glia and show dye-coupling after the intracellular injection of Neurobiotin. Scale bars: $A-F, 20 \mu \mathrm{m} ; G, H, 50 \mu \mathrm{m} ; I, 20 \mu \mathrm{m}$.

5-HTP-DP. Fast and slow EPSPs were also elicited by mucosal applications of the 5-HT 1 P agonist WAY 100325. The ability of a single antagonist or agonist to block or elicit both fast and slow EPSPs is consistent with the idea that their site of action is the primary afferent, rather than the second-order neuron. Responses to mucosal 5 -HT were not inhibited by 5 - $\mathrm{HT}_{3}$-blocking concentrations of tropisetron or ondansetron. Although both fast and slow EPSPs were abolished by $5-\mathrm{HT}_{4}$-blocking concentrations of 


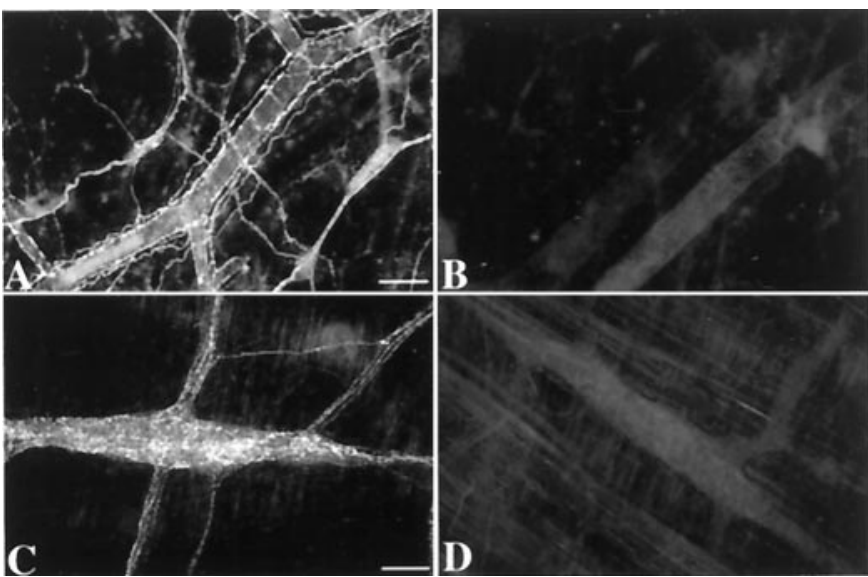

Figure 15. Sympathetic nerves were absent in loops of intestine subjected to chronic external denervation. TH immunoreactivity was used as a marker for the sympathetic innervation, which in turn served as an indicator of the completeness of extrinsic denervation. The dense array of varicose TH-immunoreactive nerve fibers can be seen in both the submucosal $(A)$ and myenteric $(C)$ plexuses of control loops of gut from the operated animals. In contrast, the denervated loops of intestine from the same animals contain no TH-immunoreactive nerve fibers in either the submucosal $(B)$ or myenteric $(D)$ plexuses. Notice that the perivascular TH-immunoreactive fibers are also lacking in the submucosa of the denervated loops of gut. The same results, showing that the extrinsic innervation was eliminated, were obtained in three of three operated guinea pigs. Scale bar, $100 \mu \mathrm{m}$.

tropisetron, they were unaffected by two other $5-\mathrm{HT}_{4}$ antagonists, SB 204070 and GR 113808, and they were not evoked by mucosal applications of the $5-\mathrm{HT}_{4}$ agonist BIMU-8. These data suggest that 5 -HT activates $5-\mathrm{HT}_{1 \mathrm{P}}$ receptors on the mucosal processes of submucosal primary afferent neurons. Because tropisetron, even at high concentrations, does not antagonize $5-\mathrm{HT}_{1 \mathrm{P}}$ receptors (Craig and Clarke, 1990; Pan et al., 1997), the effect of tropisetron might be attributable to a splice variant of the $5-\mathrm{HT}_{4}$ receptor (Blondel et al., 1998; Bockaert et al., 1998; Claeysen et al., 1998, 1999) that is unexpectedly insensitive to SB 204070 and GR 113808. Although the $5-\mathrm{HT}_{1 \mathrm{P}}$ receptor, which is coupled to $\mathrm{G}_{\mathrm{o}}$ (Pan et al., 1997), is different from the 5- $\mathrm{HT}_{4}$ receptor, which is coupled to $\mathrm{G}_{\mathrm{s}}$ (Hamblin et al., 1998), both receptors increase cAMP. Conceivably, therefore, an interactive effect that is inhibited by tropisetron is elicited when $5-\mathrm{HT}_{1 \mathrm{P}}$ and $5-\mathrm{HT}_{4}$ receptors are stimulated simultaneously. Alternatively, the action of tropisetron might be nonspecific.
The hypothesis that the activation of submucosal primary afferent neurons by mechanical stimulation of the mucosa is mediated by the release of 5-HT (Bülbring and Crema, 1958, 1959a,b; Bülbring and Lin, 1958; Bülbring et al., 1958; Wade et al., 1990, 1996; Kirchgessner et al., 1992, 1996; Foxx-Orenstein et al., 1995; Sidhu and Cooke, 1995; Grider et al., 1996; Cooke et al., 1997) predicts that the response of these neurons to mechanical stimulation would be inhibited by the same antagonists that block their response to mucosally applied 5-HT. In fact, responses of submucosal neurons to mechanical stimulation of the mucosa were blocked by 5-HTP-DP and tropisetron and not by ondansetron. These observations thus support the hypothesis that the 5-HT that is released from the mucosa by mechanical stimulation activates the mucosal processes of submucosal primary afferent neurons. This hypothesis is further strengthened by the earlier observation that the number of submucosal primary afferent neurons responding to mechanical stimulation of the mucosa is increased by 5 -HT reuptake inhibitors (Wade et al., 1996; Chen et al., 1998).

$5-\mathrm{HT}_{1 \mathrm{P}}$ and $5-\mathrm{HT}_{4}$ receptors have previously been reported to activate the peristaltic reflex and stimulate the release of CGRP from submucosal neurons (Grider et al., 1996, 1998; Wade et al.,

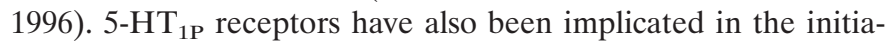
tion of secretory reflexes in preparations without the myenteric plexus (Sidhu and Cooke, 1995; Cooke et al., 1997). These data are consistent with the idea that $5-\mathrm{HT}_{1 \mathrm{P}}$ receptors are present on the mucosal processes of submucosal primary afferent neurons but that $5-\mathrm{HT}_{3}$ receptors are not. $5-\mathrm{HT}_{3}$ antagonists have been reported to be unable, by themselves, to antagonize peristaltic (Kadowaki et al., 1996; Nagakura et al., 1997; Grider et al., 1998) or secretory (Sidhu and Cooke, 1995; Cooke et al., 1997) reflexes, and they do not interfere with the release of CGRP by mucosal stimulation (Grider et al., 1998). Reflexes initiated by submucosal primary afferent neurons are thus $5-\mathrm{HT}_{3}$-independent. $5-\mathrm{HT}_{3}$ receptors, however, have been reported to activate myenteric primary afferent neurons (Bertrand et al., 1999) and partially inhibit propulsion in the canine jejunum (Neya et al., 1993). $5-\mathrm{HT}_{3}$ receptors also activate extrinsic sensory nerves (Blackshaw and Grundy, 1993; Grundy et al., 1994; Hillsley and Grundy, 1998). It thus seems likely that different 5-HT receptor subtypes can differentially activate subsets of enteric primary afferent neurites. This possibility might explain why $5-\mathrm{HT}_{3}$ receptors do not participate in normal intestinal propulsion but become involved when intestinal propulsion becomes abnormal, as in en-

Table 3. Chemical coding of submucosal neurons that respond to mucosal applications of 5-HT

\begin{tabular}{|c|c|c|c|c|c|c|}
\hline & $\begin{array}{l}\text { Neurons } \\
\text { (total) }\end{array}$ & NPY & $\begin{array}{l}\text { Dynorphin }{ }^{+} / \\
\text {NPY }^{-}\end{array}$ & CGRP & Calbindin & Calretinin \\
\hline $\begin{array}{l}\text { Putative } \\
\text { function }\end{array}$ & & $\begin{array}{l}\text { Cholinergic } \\
\text { secretomotor }^{a}\end{array}$ & $\begin{array}{l}\text { VIP secreto- } \\
\text { motor }^{b}\end{array}$ & $\begin{array}{l}\text { Cholinergic } \\
\text { secretomotor } \\
\text { or } ?^{d}\end{array}$ & $\begin{array}{l}\text { Cholinergic } \\
\text { primary } \\
\text { afferent }^{e}\end{array}$ & $\begin{array}{l}\text { Cholinergic } \\
\text { interneurons }^{c}\end{array}$ \\
\hline Fast EPSP & $26 / 39$ & $4 / 26$ & $2 / 20$ & $0 / 4$ & $0 / 26$ & $2 / 7$ \\
\hline Slow EPSP & $13 / 39$ & $0 / 13$ & $0 / 13$ & $2 / 6$ & $0 / 10$ & \\
\hline
\end{tabular}

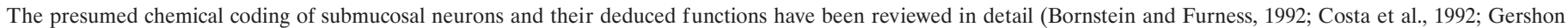
et al., 1994).

${ }^{a}$ Putative coding: ChAT/CGRP/dynorphin/CCK/neuromedin U/NPY/somatostatin.

${ }^{b}$ Putative coding: VIP/dynorphin/galanin/neuromedin U.

${ }^{c}$ Putative coding: ChAT/calretinin.

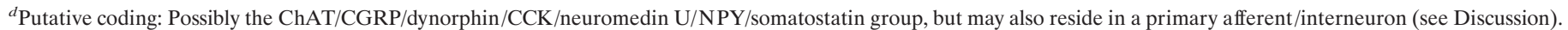

${ }^{e}$ Putative coding: ChAT/substance $\mathrm{P} /$ calbindin. 
teric anaphylaxis (Clayton et al., 1999). The failure of 5-HT antagonists to block reflexes required for normal intestinal motility is consistent with the idea that these reflexes are initiated by the $5-\mathrm{HT}_{3}$-independent primary afferent neurons of the submucosal plexus and not by myenteric primary afferent neurons, which are $5-\mathrm{HT}_{3}$-dependent.

The primary afferent neurons activated by mucosal 5-HT appear to be cholinergic, and at least some cells of this population also use CGRP as a slow transmitter. Fast EPSPs evoked by these cells in second-order neurons thus were blocked by hexamethonium, whereas slow EPSPs were abolished in a majority of cells by the CGRP antagonist hCGRP ${ }_{8-37}$. This antagonist also blocked the effects of exogenous CGRP, which mimicked slow EPSPs when applied directly to submucosal neurons. The physiological data supporting a role for CGRP was supported by the observations that hCGRP $_{8-37}$ inhibited both the stimulation-induced uptake of FM2-10 and the stimulation-dependent expression of Fos. Photoconversion of FM2-10 to a DAB reaction product made it possible to demonstrate that at least some of the cells stimulated to take up FM2-10 did, in fact, contain CGRP immunoreactivity. These observations agree well with the previous report that mechanical stimulation leads to the secretion of 5-HT from the mucosa and that the secreted 5-HT evokes the release of CGRP from submucosal neurons (Grider, 1994; Grider et al., 1996, 1998). Collaterals of extrinsic sensory neurons were not responsible for slow or fast EPSPs evoked by mucosal stimulation in submucosal neurons because neither was affected by chronic extrinsic denervation.

CGRP does not appear to be the only slow neurotransmitter of primary afferent neurons. Scopolamine antagonized slow EPSPs in 1 of 10 cells, suggesting that rare slow EPSPs are muscarinic. Others were inhibited neither by hCGRP $_{8-37}$ nor by scopolamine. No evidence was found to suggest that slow EPSPs evoked in second-order cells by primary afferent neurons are mediated by neurokinin (Kirchgessner et al., 1992; Furness et al., 1998; Li and Furness, 1998) or NMDA receptors. Glutamate may still play such a role (Liu et al., 1997), perhaps by activating metabotrophic receptors, which were not investigated.

Impaled neurons were marked for subsequent identification by microinjection of Neurobiotin. Cells that did not respond to mucosal 5-HT were found to be glia, which were dye-coupled, as reported previously (Hanani et al., 1989). Some of the secondorder neurons that responded to the mucosal application of 5-HT were immunocytochemically identified. Fast EPSPs were recorded in neurons that contained NPY, dynorphin (but not NPY), or calretinin. Deductive studies (Bornstein and Furness, 1992; Costa et al., 1992; Gershon et al., 1994; Furness et al., 1995b) have suggested that NPY may mark cholinergic secretomotor neurons, dynorphin (without NPY) may mark VIPcontaining secretomotor neurons, and calretinin may mark cholinergic interneurons. Slow EPSPs were encountered in CGRPcontaining cells. The latter have variously been considered to be cholinergic secretomotor neurons that co-store many neuropeptides (Furness et al., 1995b), or primary afferent cells (Grider, 1994). Myenteric primary afferent neurons are also interneurons, in the sense that they make connections with one another and transmit primarily via slow EPSPs (Kunze and Furness, 1999). The submucosal primary afferent population may similarly be multifunctional, serving both a primary afferent and a secretomotor purpose. The presence of CGRP in second-order neurons raises the possibility that submucosal CGRP-containing multi- functional primary afferent neurons synapse on one another, like their myenteric counterparts.

In summary, the data support the hypothesis that 5-HT released from EC cells after mucosal stimulation initiates reflexes by activating $5-\mathrm{HT}_{1 \mathrm{P}}$ receptors on submucosal primary afferent neurons. Second-order neurons respond to the cholinergic/ CGRP-containing primary afferent cells with nicotinic fast EPSPs and/or CGRP-mediated slow EPSPs. Slow EPSPs are necessary to allow excitation to spread within the submucosal plexus.

\section{REFERENCES}

Bertrand PP, Kunze WAA, Bornstein JC, Furness JB, Smith ML (1997) Analysis of the responses of myenteric neurons in the small intestine to chemical stimulation of the mucosa. Am J Physiol 36:G422-G435.

Bertrand PP, Furness JB, Bornstein JC (1999) 5-HT and ATP stimulate the mucosal terminals of some myenteric sensory neurons and cause increases in excitability in a population of sensory neurons. Falk Symposium No. 112. Neurogastroenterology: from the basics to the clinics. Falk Foundation: Freiburg, Germany.

Betz WJ, Bewick GS (1992) Optical analysis of synaptic vesicle recycling at the frog neuromuscular junction. Science 255:200-203.

Betz WJ, Mao F, Bewick GS (1992) Activity-dependent fluorescent staining and destaining of living motor nerve terminals. J Neurosci $12: 363-375$.

Beubler E, Kollar G, Saria A, Bukhave K, Rask-Madsen J (1989) Involvement of 5-hydroxytryptamine, prostaglandin $\mathrm{E}_{2}$, and cyclic adenosine monophosphate in cholera toxin-induced fluid secretion in the small intestine of the rat in vivo. Gastroenterology 96:368-376.

Blackshaw LA, Grundy D (1993) Effects of 5-hydroxytryptamine on discharge of vagal mucosal afferent fibres from the upper gastrointestinal tract of the ferret. J Auton Nerv Syst 45:41-50.

Blondel O, Gastineau M, Dahmoune Y, Langlois M, Fischmeister R (1998) Cloning, expression, and pharmacology of four human 5-hydroxytryptamine 4 receptor isoforms produced by alternative splicing in the carboxyl terminus. J Neurochem 70:2252-2261.

Bockaert J, Sebben M, Dumuis A (1990) Pharmacological characterization of 5-hydroxytryptamine ${ }_{4}\left(5-\mathrm{HT}_{4}\right)$ receptors positively coupled to adenylate cyclase in adult guinea pig hippocampal membranes: effect of substituted benzamide derivatives. Mol Pharmacol 37:408-411.

Bockaert J, Claeysen S, Sebben M, Dumuis A (1998) 5-HT4 receptors: gene, transduction and effects on olfactory memory. Ann NY Acad Sci 861:1-15.

Bornstein JC, Furness JB (1992) Enteric neurons and their chemical coding. In: Advances in the innervation of the gastrointestinal tract (Holle GE, Wood JD, eds), pp 101-114. New York: Elsevier.

Boullin DJ (1964) Observations on the significance of 5-hydroxytryptamine in relation to the peristaltic reflex of the rat. Br J Pharmacol 23:14-33.

Branchek TA, Kates M, Gershon MD (1984) Enteric receptors for 5-hdyroxytryptamine. Brain Res 324:107-118.

Branchek T, Mawe G, Gershon MD (1988) Characterization and localization of a peripheral neural 5-hydroxytryptamine receptor subtype with a selective agonist, ${ }^{3} \mathrm{H}-5$-hydroxyindalpine. J Neurosci 8:2582-2595.

Bülbring E, Crema A (1958) Observations concerning the action of 5-hydroxytryptamine on the peristaltic reflex. $\mathrm{Br} \mathrm{J}$ Pharmacol 13:444-457.

Bülbring E, Crema A (1959a) The action of 5-hydroxytryptamine, 5-hydroxytryptophan and reserpine on intestinal peristalsis in anaesthetized guinea-pigs. J Physiol (Lond) 146:29-53.

Bülbring E, Crema A (1959b) The release of 5-hydroxytryptamine in relation to pressure exerted on the intestinal mucosa. J Physiol (Lond) 146:18-28

Bülbring E, Lin RCY (1958) The effect of intraluminal application of 5-hydroxytryptamine and 5-hydroxytryptophan on peristalsis, the local production of 5-hydroxytryptamine and its release in relation to intraluminal pressure and propulsive activity. J Physiol (Lond) 140:381-407.

Bülbring E, Lin RCY, Schofield G (1958) An investigation of the peristaltic reflex in relation to anatomical observations. Q J Exp Physiol 43:26-37.

Cassuto J, Jodal M, Tuttle R, Lundgren O (1982) 5-Hydroxytryptamine and cholera secretion. Scand J Gastroenterol 17:695-703.

Cassuto J, Siewert A, Jodal M, Lundgren O (1983) The involvement of 
intraluminal nerves in cholera toxin induced intestinal secretion. Acta Physiol Scand 117:195-202.

Chen J-X, Pan H, Rothman TP, Wade PR, Gershon MD (1998) Guinea pig 5-HT transporter: cloning, expression, distribution and function in intestinal sensory reception. Am J Physiol 275:G433-G448.

Claeysen S, Faye P, Sebben M, Taviaux S, Bockaert J, Dumuis A (1998) 5-HT4 receptors: cloning and expression of new splice variants. Ann NY Acad Sci 861:49-56.

Claeysen S, Sebben M, Becamel C, Bockaert J, Dumuis A (1999) Novel brain-specific 5-HT4 receptor splice variants show marked constitutive activity: role of the C-terminal intracellular domain. Mol Pharmacol 55:910-920.

Clayton NM, Sargent R, Butler A, Gale J, Maxwell MP, Hunt AAE, Barrett VJ, Cambridge D, Bountra C, Humphrey PPA (1999) The pharmacological properties of the novel selective 5-HT3 receptor antagonist, alosetron, and its effects on normal and perturbed small intestinal transit in the fasted rat. Neurogastroenterol Motil 11:207-217.

Cooke HJ (1989) Role of the "little brain" in the gut in water and electrolyte homeostasis. FASEB J 3:127-138.

Cooke HJ, Sidhu M, Wang Y-Z (1997) 5-HT activates neural reflexes regulating secretion in the guinea-pig colon. Neurogastroenterol Motil 9:181-186.

Costa M, Furness JB, Cuello AC, Verhofstad AAJ, Steinbusch HWJ, Elde RP (1982) Neurons with 5-hydroxytryptamine-like immunoreactivity in the enteric nervous system: their visualization and reactions to drug treatment. Neuroscience 7:351-363.

Costa M, Brookes S, Waterman S, Mayo R (1992) Enteric neuronal circuitry and transmitters controlling intestinal motor function. In: Advances in the innervation of the gastrointestinal tract (Holle GE, Wood JD, eds), pp 115-121. New York: Elsevier.

Craig DA, Clarke DE (1990) Pharmacological characterization of a neuronal receptor for 5-hydroxytryptamine in guinea pig ileum with properties similar to the 5-hydroxytryptamine ${ }_{4}$ receptor. J Pharmacol Exp Ther 252:1378-1386.

Cunningham SM, Hirai K, Mihara S, Lees GM (1997) Electrophysiological characteristics of submucosal neurones in the proximal colon of guinea-pigs: comparisons with caecum and descending colon. Exp Physiol 82:859-870.

Evans RJ, Jiang MM, Surprenant A (1994) Morphological properties and projections of electrophysiologically characterized neurons in the guinea-pig submucosal plexus. Neuroscience 59:1093-1100.

Foxx-Orenstein AE, Kuemmerle JF, Grider JR (1995) The peristaltic reflex induced by mucosal stimuli in human and guinea pig intestine is mediated by distinct mucosal 5-HT receptors. Gastroenterology 108:A600.

Furness JB, Costa M (1982) Neurons with 5-hydroxytryptamine-like immunoreactivity in the enteric nervous system: their projections in the guinea pig small intestine. Neuroscience 7:341-350.

Furness JB, Costa M (1987) The enteric nervous system. New York: Churchill Livingstone.

Furness JB, Johnson PJ, Pompolo S, Bornstein JC (1995a) Evidence that enteric motility reflexes can be initiated through entirely intrinsic mechanisms in the guinea-pig small intestine. Neurogastroenterol Motil 7:89-96.

Furness JB, Young HM, Pompolo S, Bornstein JC, Kunze WAA, McConalogue K (1995b) Plurichemical transmission and chemical coding of neurons in the digestive tract. Gastroenterology 108:554-563.

Furness JB, Kunze WA, Bertrand PP, Clerc N, Bornstein JC (1998) Intrinsic primary afferent neurons of the intestine. Prog Neurobiol 54:1-18.

Galligan JJ, North RA (1991) Opioid, 5- $\mathrm{HT}_{1 \mathrm{~A}}$ and $\alpha_{2}$ receptors localized to subsets of guinea-pig myenteric neurons. J Auton Nerv Syst 32:1-12.

Galligan JJ, Costa M, Furness JB (1988) Changes in surviving nerve fibers associated with submucosal arteries following extrinsic denervation of the small intestine. Cell Tissue Res 253:647-656.

Gershon MD, Kirchgessner AL, Wade PR (1994) Functional anatomy of the enteric nervous system. In: Physiology of the gastrointestinal tract, Ed 3 (Johnson LR, Alpers DH, Jacobson ED, Walsh JH, eds), pp 381-422. New York: Raven.

Grider JR (1994) CGRP as a transmitter in the sensory pathway mediating peristaltic reflex. Am J Physiol 266:G1139-1145.

Grider JR, Jin J-G (1994) Distinct populations of sensory neurons me- diate the peristaltic reflex elicited by muscle stretch and mucosal stimulation. J Neurosci 14:2854-2860.

Grider JR, Kuemmerle JF, Jin JG (1996) 5-HT released by mucosal stimuli initiates peristalsis by activating 5-HT4/5-HT1p receptors on sensory CGRP neurons. Am J Physiol 270:G778-782.

Grider JR, Foxx-Orenstein AE, Ji-Guang J (1998) 5-Hydroxytryptamine $_{4}$ receptor agonists initiate the peristaltic reflex in human, rat, and guinea pig intestine. Gastroenterology 115:370-380.

Grundy D, Blackshaw LA, Hillsley K (1994) Role of 5-hydroxytryptamine in gastrointestinal chemosensitivity. Dig. Dis Sci 39[Suppl 12 Suppl]:44S-47S.

Hamblin MW, Guthrie CR, Kohen R, Heidmann DE (1998) Gs proteincoupled serotonin receptors: receptor isoforms and functional differences. Ann NY Acad Sci 861:31-37.

Hanani M, Zamir O, Baluk P (1989) Glial cells in the guinea pig myenteric plexus are dye coupled. Brain Res 497:245-249.

Hillsley K, Grundy D (1998) Sensitivity to 5-hydroxytryptamine in different afferent subpopulations within mesenteric nerves supplying the rat jejunum. J Physiol (Lond) 509:717-727.

Jiang M-M, Kirchgessner A, Gershon MD, Surprenant A (1993) Cholera toxin-sensitive neurons in guinea pig submucosal plexus. Am J Physiol 264:G86-G94.

Kadowaki M, Wade PR, Gershon MD (1996) Participation of 5-HT3, 5-HT4, and nicotinic receptors in the peristaltic reflex of the guinea pig distal colon. Am J Physiol 271:G849-G857.

Kirchgessner AL, Mawe GM, Gershon MD (1990) Evaluation of the activity of chemically identified enteric neurons through the histochemical detection of cytochrome oxidase. J Comp Neurol 301:1-14.

Kirchgessner AL, Tamir H, Gershon MD (1992) Identification and stimulation by serotonin of intrinsic sensory neurons of the submucosal plexus of the guinea pig gut: activity-induced expression of Fos immunoreactivity. J Neurosci 12:235-249.

Kirchgessner AL, Liu M-T, Gershon MD (1996) In situ identification and visualization of neurons that mediate enteric and enteropancreatic reflexes. J Comp Neurol 371:270-286.

Kunze WAA, Furness JB (1999) The enteric nervous system and regulation of intestinal motility. Annu Rev Physiol 61:117-142.

Kunze WA, Bornstein JC, Furness JB (1995) Identification of sensory nerve cells in a peripheral organ (the intestine) of a mammal. Neuroscience 66:1-4.

Kunze WAA, Furness JB, Bertrand PP, Bornstein JC (1998) Intracellular recording from myenteric neurons of the guinea-pig ileum that respond to stretch. J Physiol (Lond) 506:827-842.

Li ZS, Furness JB (1998) Immunohistochemical localisation of cholinergic markers in putative intrinsic primary afferent neurons of the guinea pig small intestine. Cell Tissue Res 294:35-43.

Li ZS, Fox-Threlkeld JE, Furness JB (1998) Innervation of intestinal arteries by axons with immunoreactivity for the vesicular acetylcholine transporter (VAChT). J Anat 192:107-117.

Liu M-T, Rothstein JD, Gershon MD, Kirchgessner AL (1997) Glutamatergic enteric neurons. J Neurosci 17:4764-4784.

Mawe GM, Gershon MD (1986) Functional heterogeneity in the myenteric plexus: demonstration using cytochrome oxidase as a verified cytochemical probe of the activity of individual enteric neurons. J Comp Neurol 249:381-391.

Mawe GM, Branchek T, Gershon MD (1986) Peripheral neural serotonin receptors: identification and characterization with specific agonists and antagonists. Proc Natl Acad Sci USA 83:9799-9803.

Morgan J, Curran T (1991) Stimulus-transcription coupling in the nervous system: involvement of the inducible proto-oncogenes fos and jun. Annu Rev Neurosci 14:421-451.

Nagakura Y, Kontoh A, Tokita K, Tomoi M, Shimomura K, Kadowaki M (1997) Combined blockade of 5-HT3- and 5-HT4-serotonin receptors inhibits colonic functions in conscious rats and mice. J Pharmacol Exp Ther 281:284-290.

Neya T, Mizutani M, Yamasato T (1993) Role of 5-HT3 receptors in peristaltic reflex elicited by stroking the mucosa in the canine jejunum. J Physiol (Lond) 471:159-173.

Nilsson O, Cassuto J, Larsson P-A, Jodal M, Lidberg P, Ahlman H, Dahlstrom A, Lundgren O (1983) 5-Hydroxytryptamine and cholera secretion: a histochemical and physiological study in cats. Gut 24:542-548.

Pan H, Galligan JJ (1994) 5- $\mathrm{HT}_{1 \mathrm{~A}}$ and 5- $\mathrm{HT}_{4}$ receptors mediate inhibition and facilitation of fast synaptic transmission in enteric neurons. Am J Physiol 266:G230-G238. 
Pan H, Wang H-Y, Friedman E, Gershon MD (1997) Mediation by protein kinases $\mathrm{C}$ and $\mathrm{A}$ of $\mathrm{G}_{\mathrm{o}}$-linked slow responses of enteric neurons to 5-HT. J Neurosci 17:1011-1024.

Parr EJ, Sharkey KA (1994) The use of constitutive oncoproteins to count neurons in the enteric nervous system of the guinea pig. Cell Tissue Res 277:325-331.

Sidhu M, Cooke HJ (1995) Role for 5-HT and ACh in submucosal reflexes mediating colonic secretion. Am J Physiol 269:G346-G351.

Takaki M, Branchek T, Tamir H, Gershon MD (1985a) Specific antagonism of enteric neural serotonin receptors by dipeptides of 5-hydroxytryptophan: evidence that serotonin is a mediatory of slow synaptic excitation in the myenteric plexus. J Neurosci 5:1769-1780.

Takaki M, Mawe GM, Barasch J, Gershon MD (1985b) Physiological responses of guinea-pig myenteric neurons secondary to the release of endogenous serotonin by tryptamine. Neuroscience 16:223-240.

Tsuji S, Anglade P, Ozaki T, Sazi T, Yokoyama S (1992) Peristaltic movement evoked in intestinal tube devoid of mucosa and submucosa. Jpn J Physiol 42:363-375.
Vinay L, Cazalets JR, Clarac F (1995) Evidence for the existence of a functional polysynaptic pathway from trigeminal afferents to lumbar motoneurons in the neonatal rat. Eur J Neurosci 7:143-151.

Wade PR, Tamir H, Kirchgessner AL, Gershon MD (1990) Use of anti-idiotypic antibodies to study the role of 5-HT receptors in the activation of enteric neurons. Gastroenterology 99:1234.

Wade PR, E Fiorica-Howells E, Gershon MD (1993) Analysis of the actions of a novel benzamide on colonic motility and 5-HT receptors on myenteric neurons. J Gastrointest Motil 5:223.

Wade PR, Tamir H, Kirchgessner AL, Gershon MD (1994) Analysis of the role of 5-HT in the enteric nervous system using anti-idiotypic antibodies to 5-HT receptors. Am J Physiol 266:G403-G416.

Wade PR, Chen J, Jaffe B, Kassem IS, Blakely RD, Gershon MD (1996) Localization and function of a 5-HT transporter in crypt epithelia of the gastrointestinal tract. J Neurosci 16:2352-2364.

Wang H-Y, Fiorica-Howells E, Pan H, Gershon MD, Friedman E (1996) Myenteric ganglionic 5-hydroxytryptamine ${ }_{1 \mathrm{P}}$ signal transmission is mediated via Go protein. J Pharmacol Exp Ther 277:518-524. 